\title{
Of actors, functions, and fuels: Exploring a second generation ethanol transition from a technological innovation systems perspective in Brazil
}

\author{
André Tosi Furtado ${ }^{\mathrm{a}, *}$, Marko P. Hekkert ${ }^{\mathrm{b}}$, Simona O. Negro ${ }^{\mathrm{b}}$ \\ ${ }^{a}$ Department of Science and Technology Policy, Institute of Geosciences, University of Campinas, Rua Carlos Gomes, 250, CEP: 13083-855 Campinas, SP, Brazil \\ ${ }^{\mathrm{b}}$ Copernicus Institute for Sustainable Development and Innovation, Faculty of Geosciences, University of Utrecht, Heidelberglaan 8, 3584 CS Utrecht, The Netherlands
}

\section{A R T I C L E I N F O}

\section{Keywords:}

Technological innovation system

Function analysis

Biofuels

Cellulosic ethanol

Enzymatic hydrolysis

Energy cane

Sugarcane

\begin{abstract}
A B S T R A C T
This article analyzes the transition towards second-generation (2G) biofuels during the 2005-2018 period in Brazil, which is a world leader of first-generation (1G) biofuels. In the case of Brazil 2G technologies are associated with sugarcane and the technologies of this transition considered in this article are enzymatic hydrolysis and energy cane. The analytical background used is the technological innovation systems (TIS) framework. The functioning of the innovation system is studied using scientific papers, patents, reports, newspaper information, and other data from Brazilian funding agencies. The paper examines how the functions of the Brazilian bioethanol TIS related to $2 \mathrm{G}$ biofuels operated and were interconnected in this period. We found that the knowledge development and resource mobilization functions operated positively but others did not, especially guidance of the search, market formation and creation of legitimacy, revealing an unbalanced system transformation. During this period there were two important phases, one dominated by academic actors and the other by the federal development bank. However, we found that the functions were not enough to explain the TIS evolution, and that the external context of the global TIS and the Brazilian macroeconomic dynamic were also very important to explain this evolution. We conclude that the transition was not completed and that in the future policies should consider system dynamics and context evolution.
\end{abstract}

\section{Introduction}

The necessary reduction of greenhouse gas emissions involves deep transformation in the energy system of modern societies. The primary energy supply must move chiefly from fossil fuels towards renewable and sustainable energy sources. The implications of this energy transition for contemporary societies are huge. Renewable energy sources must undergo intense processes of learning. Their diffusion will depend on a great number of innovations in a wide range of technologies before they can compete with fossil fuel technologies. This innovation process will take time and requires long-term policy support.

Biomass is one kind of renewable energy source. The key benefit of this primary source is that it can replace liquid fossil fuels in the transportation sector, for which other alternatives are hardly conceivable $^{1}$. In spite of its great importance as a primary energy source, biomass is also a contested energy alternative due to controversies about its sustainability.

Goldemberg and Coelho [2] separate, in terms of sustainability, traditional from modern biomass ${ }^{2}$ where modern biomass is a much more sustainable energy source. However, this kind of optimism about modern biomass is vulnerable to several criticisms [3]. First, energy crops can displace food crops or be a cause of deforestation in tropical areas [4]. Second, the energy-GHG balance, in the case of corn-based bioethanol, is not very favorable [5]. Third, working conditions, as in the case of sugarcane harvesting, are problematic and unsustainable [6]. Finally, energy crops can also have a direct negative impact on the environment due to straw burning before harvesting, leading to local air pollution and the abusive use of chemical fertilizers, pesticides and

\footnotetext{
* Corresponding author.

E-mail address: afurtado@unicamp.br (A.T. Furtado).

${ }^{1}$ According to IEA Figures, the transportation sector accounted for $64.5 \%$ of world oil consumption in 2016 [1]. According to the same source, biomass is the first renewable primary energy source, accounting for $9.8 \%$ of the world energy supply in the same year.

${ }^{2}$ Traditional biomass is largely consumed at world level by rural populations in poor countries. In most cases, this kind of biomass is collected from the natural environment, especially as fuelwood, with unsustainable predatory methods. The collection and consumption techniques of this biomass are also harmful to the health and life conditions of the rural population. Modern biomass includes bioelectricity, heat production and liquid fuels from energy crops and agricultural and forest residues, as well as from solid waste. The production process is cleaner and the recovery of the biomass energy potential is much higher than with traditional methods. The final energy products are converted with much cleaner technologies also.
} 
antibiotics which pollute water and soil [7].

Thus, achieving sustainable use of biomass requires a technological transition in the modern biomass system. Basically, we need a double transition to create a future for sustainable biomass, first from a traditional and low productivity biomass system to a modern one, and second from a modern but unsustainable system to a modern and sustainable system [8].

Brazilian bioethanol is a very good example of this kind of double transition. First, the sugarcane production system has undergone the transition from low to high productivity. This process happened almost entirely in the last century. However, as bioethanol became the main sugarcane product, there was an increasing demand for higher social and environmental sustainability standards. Some of these technological changes started to happen in the 1980s, like the use of vinasse in fertirrigation ${ }^{3}$. Since the last decade there has been an important increase in the use of more efficient boilers in sugar mills alongside cogeneration, allowing the increase of bioelectricity production in Brazil ${ }^{4}$. The Environmental Protocol signed in 2007 by sugarcane mills and the Government of São Paulo allowed a fast penetration of mechanical harvesting in that state, eliminating straw burning and reducing the need for unskilled labor.

One of the greatest challenges of bioethanol sustainability is land requirement, even with sugarcane being one of the most productive energy crops and Brazil having great availability of free land outside the Amazonian region $[10,11]$. The sugarcane area has almost doubled since the beginning of the century. This expansion is happening not only in São Paulo state but also in the Brazilian Center-West region, were climatic conditions are very different from the southern states.

Due to this expansion in the last decade, the technological trajectory of the Brazilian bioethanol TIS is reaching its limits. In this regard, the technological system built around the so-called $1 \mathrm{G}$ (first-generation) technologies is attaining decreasing rates of return. Some of these problems are noticeable by the difficulty of Brazilian sugarcane and bioethanol production to increase since the beginning of the last decade ${ }^{5}$.

These difficulties faced by the sugarcane technological system are simultaneous with important technological ruptures. There are several technological innovations related to the emergence of the so-called bioeconomy, which includes a large range of new technologies concerning biofuels, bioproducts and biopower [13]. These technologies are highly relevant to achieve sustainable development goals and the transition towards a circular economy [14]. Among this wide range of new technologies, cellulosic ethanol, called 2G (second-generation) technologies, is considered one of the most viable alternatives to improve productivity and reduce biofuel production costs $[15,16]$. Indeed, with this new technological generation, the biofuels industry can increase its production without facing the same land requirements of $1 \mathrm{G}$ technologies.

Nevertheless, the transition from $1 G$ to $2 \mathrm{G}$ technologies implies a great leap forward for a developing country like Brazil which has based its own development on incremental innovations [17]. Important public actors like Fapesp and the federal government have been engaged in trying to create favorable conditions for this leap. Thus, our main question is: under what conditions can the Brazilian bioethanol TIS achieve its transition to $2 \mathrm{G}$ technologies?

\footnotetext{
${ }^{3}$ Vinasse is a residue from sugar juice fermentation that was previously stocked in small dams and later discarded in rivers. With the fertirrigation process, vinasse was used for land irrigation, reducing substantially land potassium requirements, but also the environmental impact.

${ }^{4}$ Bioelectricity generation from sugarcane was 35,656 GWh in 2017 , accounting for $6.1 \%$ of Brazilian total electricity generation. This output has increased $193 \%$ since 2008 [9].

${ }^{5}$ Brazilian bioethanol production, which was 27,376 thousand cubic meters in $2010 / 2011$, only increased to 27,859 thousand cubic meters in the 2017 / 2018 harvest year [12].
}

\section{Technological innovation systems in developing countries}

Innovation was understood by Schumpeter to be an isolated act generated by lonely entrepreneurs [18]. However, even this author considered credit capital an important complementary actor in the innovation process. In the 1980s a new approach suggested that companies were not single actors but rather embedded in a national system of innovation [19]. Additional important actors like other companies, research and human resources training organizations, government agencies, besides public policies, played a relevant role in the innovation process. Innovation should be understood as an interactive process among many and sometimes very different actors. Governments were seen as important actors to contribute to the smooth functioning of National Innovation Systems through a wide range of innovation-stimulating interventions like R\&D subsidies and the establishment of technological institutes [20].

Nonetheless, the idea of a system was not only applied at the level of nation states but also to different kind of technologies that were complementary and allowed general technological advances in a given area. Freeman and Perez [21] define a technological system as a meso-level unit of analysis, which is a combination of incremental and radical innovations that together with managerial and organizational innovations affect more than a few companies. This idea made it possible to understand how different industries and companies have to interact to contribute to technological progress.

The technological innovation system (TIS) approach that was initiated by Carlsson and Stankiewicz [22] can be understood as a combination of those two previous approaches to innovation systems. In this approach the interactions among actors are supposed to happen at the level of a certain technological field. TIS is defined as a sociotechnical system where agents interact within a certain institutional arrangement to generate, diffuse and use a set of interdependent technologies [23-26].

The technological innovation system approach introduced a new perspective in innovation systems thinking $[26,27]$. While the previous literature about innovation systems focused on analyzing the structure of the innovation system-the main organizations and institutions, and the relationships and connection among them through networks-the authors, working on the technological innovation system framework, introduced the concept of system functions. These system functions describe the key processes that contribute to technological generation and diffusion within an innovation system. Therefore, the focus shifted from studying who is present in an innovation system to what is actually achieved in the innovation system. This approach proposes seven system functions: 1 . entrepreneurial activities, 2. knowledge development, 3. knowledge diffusion through networks, 4. guidance of the search, 5. market formation, 6 . resource mobilization, and 7. creation of legitimacy [27]. These functions are also understood to be interdependent, reinforcing or weakening each other, and the general innovation process depends on the fulfillment of these system functions.

There are mutual reinforcing mechanisms between the functions of the system. Motors of innovation can be understood as positive feedback mechanisms that happen between functions [27]. These feedback mechanisms are always mediated by agents in the innovation system. These feedback loops or virtuous cycles accelerate the growth of innovation systems. According to [28,29] different types of motors may emerge in different phases of the development of an innovation system.

At the starting point TIS were conceived to operate at a global scale because "the boundaries of technological systems do not coincide with national boundaries" [22]. However, many empirical studies using this approach often focused on the national scale [30], because many actors, institutions and functions operate at this level. Often the technologies may vary among countries due to certain raw materials and others inputs.

This is why context is an important aspect to explain the functioning of a TIS [31]. Context can be understood as a large set of factors that 
effectively influences the behavior of the system but is not conditioned by actions and activities of the actors developed within the TIS. Bergek et al. [32] define three sorts of contextual structures that influence TIS behavior: other TIS, sectoral and geographical structures and political structures. We will consider mainly in this paper external geographical contexts constituted by other leading TIS that had great influence on Brazilian $2 \mathrm{G}$ bioethanol and the political context due to the decisive support from national public funding agencies for the promotion of this technology.

The functional approach is predominately used to analyze the transition to new sustainable technologies [33]. In most cases, innovation systems are analyzed in developed countries like the Netherlands, Sweden and the UK $[28,34,35]$. This has led to important insights into how new technologies emerge and what factors drive and hamper the development and diffusion of innovation in different phases of the life cycle $[36,37]$.

In spite of the great theoretical contributions, the TIS approach is not sufficiently tailored to understanding technological transitions in developing countries. The strong science base and radical innovations do not fit well with the kind of technological change that happens in developing countries, which is most of the time incremental [38-40]. When radical innovations are developed in developing countries, knowledge and resources of multinational companies from developed countries are often needed [41-43]. Innovation systems in developing countries are weak and face system failures $[44,45]$. We may expect that these facts have severe consequences for how an innovation system is influenced by national policy makers in developing countries.

Our study of the $2 \mathrm{G}$ bioethanol experience in Brazil using the TIS framework should therefore also provide insight into how the context of developing countries influences the nature of technological development. The literature on developing countries stresses that international technological transfer is only effectively assimilated when followed by indigenous technological efforts $[41,46]$. Thus, we will emphasize the role of national actors and networks in the development of new technologies, alongside the strategy of local companies to transfer technology from multinational companies.

\section{Methods}

Our starting point is studying the main actors of the bioethanol innovation system that in some measure engaged in the development of $2 \mathrm{G}$ technologies. These actors are companies (incumbents, new entrants and start-ups), universities and research centers engaged in sugarcane technology research, research funding agencies, banks and other financial entities, and state and federal governments. We analyzed the strategies and innovation-related activities of these actors concerning the technological transition to $2 \mathrm{G}$ biofuel technologies.

The main source of data was a survey of Brazilian papers and patents related to $2 \mathrm{G}$ technologies, technical information provided by public and private agents, and articles in professional journals and business newspapers. Scopus was used as a basis to measure scientific output and the INPI (Brazilian National Institute of Industrial Property) data bank was used to evaluate the patents in this field in Brazil. The main business newspaper used to obtain information about the strategy of companies and others actors was Valor Econômico.

After mapping the competencies and strategies of these actors, we analyzed the main interactions among them in networks. The existence of partnerships between actors was measured through joint authorship of scientific papers and joint inventors in patents. In the case of patents, we looked at the inventors' origins in the CV Lattes system ${ }^{6}$ to discover

\footnotetext{
${ }^{6}$ The CV Lattes system is an internet platform organized by CNPq (National Research Council) which gathers the Curriculum Vitae of almost all Brazilian researchers and graduate students. This platform gathered more than 215 thousand master and PhD CVs in 2016. Available at: http://lattes.cnpq.br/
}

their institutional origin at the time the patent was filed.

Finally, we applied a functional analysis to understand the main processes in the innovation system related to the transition to secondgeneration technologies in the 2005-2018 period. This transition has already started but is far from being concluded. For the functional analysis we applied the method as proposed by $[26,29]$. In order to enlighten issues of developing countries we focused on the indigenous technological efforts of local actors, particularly regarding the entrepreneurial and knowledge development functions.

Next we constructed a narrative in which the events described in each of the functions are connected to each other in a sort of storyline of the TIS evolution [35]. Furthermore, also based on technical information provided by public and private agents and articles in professional journals and business newspapers, we analyzed how contextual factors influenced the Brazilian bioethanol trajectory. In this paper we considered context as the external factors of the national TIS, mainly geographical and political [32]. Thus, the geographical contextual factor was the international technological innovation system associated to $2 \mathrm{G}$ ethanol. The evolution of the Brazilian bioethanol TIS is influenced by the evolution of the global innovation system because it is a subsystem of a global TIS [47]. Otherwise we will look at the influence of the Brazilian political context that changed dramatically during the second half of the past decade, focusing on how public innovation funding evolved in this period. We will basically use BNDES data because of the key importance of this national actor for innovation and investment funding in Brazil.

Our approach was mostly qualitative, even if we tried to develop quantitative indicators to measure these processes (see Table 1 for an overview).

\section{Technological background}

Brazil is a leading world sugarcane producer that has set its own trajectory in the development of ethanol production and market. However, this system is strongly influenced by the evolution of the global innovation system and how actors and technologies of one national subsystem interact with the other subsystems [47]. The way in which Brazil intended to create its trajectory to $2 \mathrm{G}$ technologies was affected by its own technological background and by the evolution of the global innovation system, mostly located in the US and Europe. As the Brazilian 1G innovation system based its trajectory on incremental innovations, the importance of coupling with leading actors was greater in order to access $2 \mathrm{G}$ technologies.

The main technology that drives $2 \mathrm{G}$ for the production of advanced biofuels is the hydrolysis of cellulose and hemicellulose. The advantage of this technology is that a much larger part of the sugarcane can be used for biofuel production ${ }^{7}$. This technology has advanced quickly in developed countries, especially in the US, based on the long-term effort of the federal government [49]. While at the beginning acid hydrolysis was more well-known and used by the industry, in the 1980s, with the development of biotechnologies, enzymatic hydrolysis became the most explored path to transform cellulose and hemicellulose into bioethanol [50].

The enzymatic hydrolysis industrial process can be split into four main stages. The first stage is pretreatment where the lignocellulose

\footnotetext{
${ }^{7}$ Sugarcane contains three main components: sugarcane juice, bagasse and straw. Each one has approximatively $1 / 3$ of the total energy content of the plant, as one ton of sugarcane contains $140 \mathrm{~kg}$ of dry biomass of bagasse, $150 \mathrm{~kg}$ of sugar and $140 \mathrm{~kg}$ of dry straw [48]. In $1 \mathrm{G}$ technologies, only sugarcane juice is almost completely processed, but bagasse is burned in sugar mills for cogeneration, with a low conversion rate, and straw is burned in the fields, associated with manual harvesting, or left as soil cover, with mechanical harvesting. $2 \mathrm{G}$ offers the opportunity to better exploit the full potential of sugarcane energy, as the cellulosic share of these two byproducts would be converted to bioethanol.
} 
Table 1

Overview of indicators and sources per system function and context factor of the Brazilian bioethanol technological innovation system.

\begin{tabular}{|c|c|c|}
\hline Functions and Context Factors & indicators & Source of Information \\
\hline F1 - Entrepreneurial Activities & $\begin{array}{l}\text { - start-ups } \\
\text { - new entrants } \\
\text { - diversifying incumbents } \\
\text { - new demonstration and industrial projects }\end{array}$ & $\begin{array}{l}\text { - Valor Econômico } \\
\text { - Company sites }\end{array}$ \\
\hline F2 - Knowledge development (learning) & $\begin{array}{l}\text { - scientific publications } \\
\text { - patent applications }\end{array}$ & $\begin{array}{l}\text { - Scopus } \\
\text { - INPI } \\
\text { - CV Lattes }\end{array}$ \\
\hline F3 - Knowledge diffusion through networks & $\begin{array}{l}\text { - New Graduate Programs } \\
\text { - Professional Associations } \\
\text { - Conferences/Network meetings } \\
\text { - joint publication } \\
\text { - joint invention }\end{array}$ & $\begin{array}{l}\text { - Valor Econômico } \\
\text { - Websites of research programs/network (UNICAMP-USP, BBEST, Bbasic, } \\
\text { FAPESP, ABBI) } \\
\text { - Scopus } \\
\text { - INPI } \\
\text { - CV Lattes }\end{array}$ \\
\hline F4 - Guidance of the search & $\begin{array}{l}\text { - Sectoral Policies } \\
\text { - Production and industrial targets } \\
\text { - Sectoral agreements }\end{array}$ & $\begin{array}{l}\text { - Government sites (BNDES, FINEP, CGEE, MME, MCTIC, FAPESP) } \\
\text { - Professional Association (ABBI) }\end{array}$ \\
\hline F5 - Market formation & $\begin{array}{l}\text { - Niche markets } \\
\text { - Tax rebates and subsidies } \\
\text { - - Environmental and energy standards }\end{array}$ & - Government sites (MCTIC, EPE, BNDES) \\
\hline F6 - Resource mobilization & - - Private and public funding & $\begin{array}{l}\text { - Fapesp Bioen Data } \\
\text { - Finep Funding Data } \\
\text { - BNDES Funding Data }\end{array}$ \\
\hline F7 - Creation of legitimacy & - - Support from the Public Opinion & $\begin{array}{l}\text { - articles in the media (Folha de São Paulo, Estado de São Paulo, Valor } \\
\text { Econômico) }\end{array}$ \\
\hline C1 - Geographical Context & - Evolution of the Global TIS & $\begin{array}{l}\text { - articles in specialized platforms (Biofuels Digest) } \\
\text { - US and Europe Reports }\end{array}$ \\
\hline C2 - Political Context & - Evolution of Public Innovation Funding & - BNDES Funding Data \\
\hline
\end{tabular}

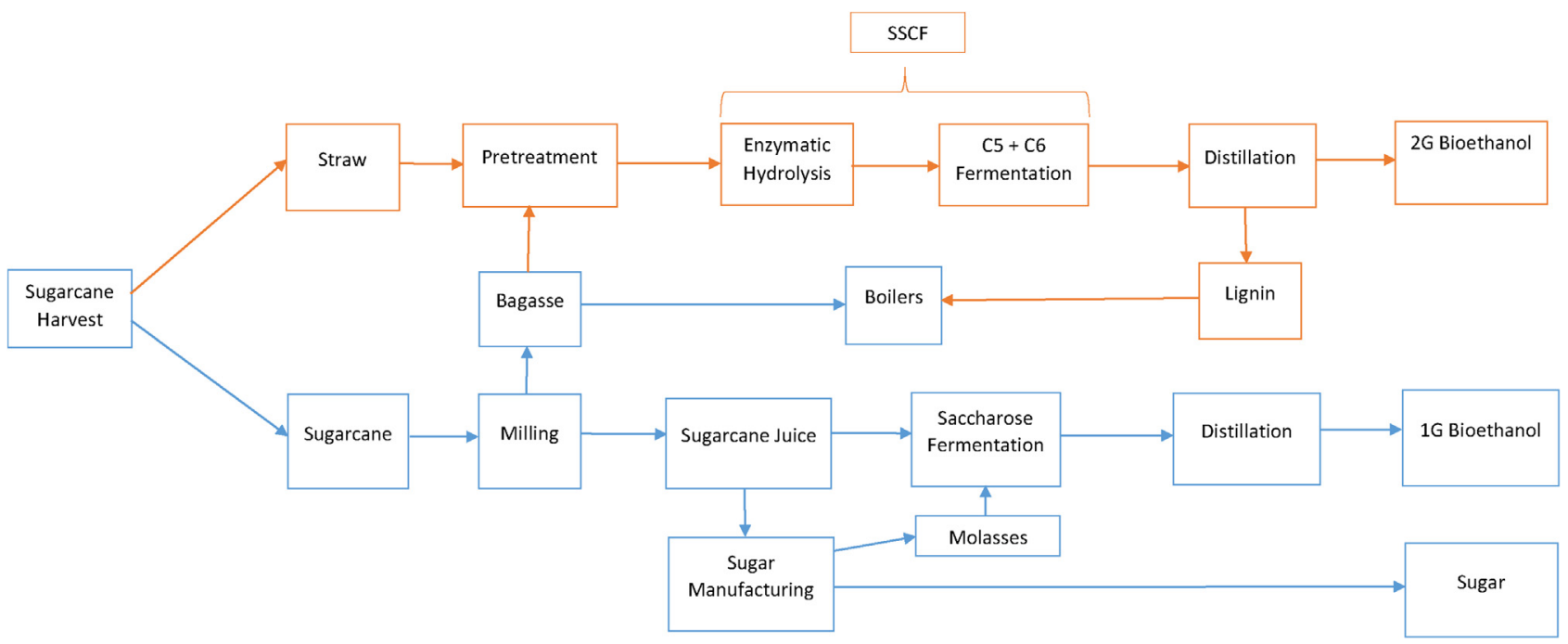

Fig. 1. Diagram of 1st and 2nd Generation Sugarcane Bioethanol.

complex is broken down, making cellulose more available to hydrolysis and generating a second stream of pentose C5 sugars. During the second stage when enzymatic hydrolysis happens, cellulose and hemicellulose are transformed into glucose C6 sugars. During the third stage C5 and C6 sugars are fermented together to produce bioethanol. The two stages - hydrolysis and fermentation of C5 and C6 sugars - can be executed together. This is the so-called simultaneous saccharification and cofermentation (SSCF) [51]. Finally, in the last phase the fermented sugars are distilled and the lignin-rich stillage is sent to co-generation of heat and power. One of the main specificities of the enzymatic hydrolysis process developed in Brazil is related to feedstock: it can be sugarcane bagasse or straw. As bagasse and straw are rich cellulose residues of the $1 \mathrm{G}$ process that are mostly unused, the main idea was to combine $1 \mathrm{G}$ and $2 \mathrm{G}$ technology in the same plant to reduce transport costs (Fig. 1). This idea became the dominant design in the industry, but was not adopted by all the projects.
All three phases of enzymatic hydrolysis face technological challenges. The conventional pretreatment process is not economically feasible and faces problems of equipment corrosion related to feedstock quality [52]. The enzymatic process is very complex and requires the development of several sorts of new enzymes to transform cellulose and hemicellulose into sugars. The solution consists in finding the right combination of different enzymes. So far, the optimal combination of enzymes has not yet been found and another unresolved issue is that the expensive enzymes cannot be recycled during the process $[47,48]$. The third phase also has important technological bottlenecks since part of the sugar resulting from the hydrolysis is not fermentable with conventional yeast. The fermentation of C5 and C6 sugars requires the development of genetic engineered yeast to process them. Such yeast does not have a high conversion rate of sugars into ethanol and cannot be recycled as in the $1 \mathrm{G}$ process [53].

The Brazilian bioethanol TIS has also developed a new variety of 
Table 2

Comparison between energy cane and conventional commercial varieties in Brazil.

\begin{tabular}{|c|c|c|c|c|}
\hline & & Conventional Sugarcane & Vignis Energy Cane & Granbio Energy Cane \\
\hline Sugarcane Productivity & Tons/ha & 80 & 180 & 180 \\
\hline Ethanol & Liters/ha & 6,800 & 10,800 & 8,000 \\
\hline Sugar & Tons/ha & 10 & 20 & 15 \\
\hline Fiber Content & $\%$ & 12.5 & 22 & 35 \\
\hline
\end{tabular}

Source: Valor Econômico, [55] based on Vignis and Granbio.

sugarcane that can fit well with cellulosic ethanol. This new variety of sugarcane, called energy cane, has higher productivity than conventional sugarcane with greater fiber and cellulose content. The development of this new variety of sugarcane started in Puerto Rico and Louisiana in the seventies after the first oil shock. Reports from the eighties showed that even if the sugar content was about half of that of commercial sugarcane, the fiber content was more than $20 \%$ higher and the total dry mass of the sugarcane per hectare was around $40 \%$ higher [54]. The engagement of Brazilian research with energy cane started at Canavialis at that time but was followed by the main sugarcane breeding programs. The results reported by the main players developing energy cane varieties were quite impressive (Table 2). The idea in Brazil was to use energy cane as feedstock to produce electricity and $2 \mathrm{G}$ ethanol. However, with some modification the energy cane could also be used to produce sugar and ethanol through the $1 \mathrm{G}$ process with a higher yield than conventional cane.

Both enzymatic hydrolysis and energy cane are expected to work together in the Brazilian bioethanol TIS. The study made by CGEE for BNDES on the feasibility of $2 \mathrm{G}$ ethanol estimates that this combination is much more attractive than producing conventional $1 \mathrm{G}$ ethanol [56].

Thus the transition of the Brazilian bioethanol TIS from $1 \mathrm{G}$ to $2 \mathrm{G}$ technologies is specific to local technological conditions but is also clearly embedded in the global biomass energy innovation system. The specific features of the TIS are related to the sugarcane feedstock and to the technological innovation system built on $1 \mathrm{G}$ technologies.

\section{Functional analysis of the Brazilian bioethanol TIS}

The 2005-2018 period was very fertile in changes in the Brazilian Bioethanol TIS. This system, which was well established in $1 \mathrm{G}$ technologies, started to progressively change its position. A narrative related to important technological ruptures started to be adopted in academia and by new relevant industrial actors. Public entities started to engage in new policies oriented towards technological rupture, in a sector where continuity was the dominant strategy.

The functional analyses will allow us to perceive these changes at different levels of the TIS. These changes have happened more or less deeply according to each function of the system. In order to understand how they performed, we will analyse each function separately. In a next section, we will give a general interpretation of these functions according to a timeline.

\subsection{Entrepreneurial experimentation}

The advent of $2 \mathrm{G}$ was followed by the arrival of new companies in the Brazilian market. Some of these actors were already experienced in $1 \mathrm{G}$ technologies but others came from new sectors like oil, chemical or biotech industries, without any tradition in bioethanol industry. Both national and foreign companies were attracted by the local advantages of Brazilian large-scale sugarcane production, which is a very competitive feedstock, and by the fact that sugarcane cellulosic ethanol of $1 \mathrm{G}$ and $2 \mathrm{G}$ technologies can be combined in the same production system. This had great impact on the entrepreneurial activity in the system. One would expect the previously established $1 G$ companies to take advantage of their incumbent position. However, this did not happen very often, and can be explained by their conservative behavior towards innovation. On the other hand, a wide range of new entrants established partnerships with sugar mills to start the production of $2 \mathrm{G}$ biofuels.

In 2011 the company Granbio was created with the purpose of developing $2 \mathrm{G}$ biofuels and biochemicals. The founders, the Grandin brothers, came from the Bahia engineering group Odebrecht. Since its beginning, the company had a very ambitious plan to produce 1 billion liters of $2 \mathrm{G}$ bioethanol in $\mathrm{Brazil}^{8}$. It developed a comprehensive plan to occupy different positions in this technological field connected to several subsidiaries: Bioflex for enzymatic hydrolysis; Biovertix for cane energy; and Biocelere for R\&D.

Granbio's strategy was to buy cellulosic hydrolysis technology as a technological package from Beta Renewables, a joint venture between Chemtex and the M\&G group that was developing this technology in its Crescentino plant in Italy. However, the Beta Renewables technology called Proesa was developed for other feedstocks that are available in Europe. In order to assess whether the Proesa technology also works for sugarcane straw and bagasse, Beta Renewables tested these feedstocks in the Crescentino plant and Granbio closed contracts with Novozymes (Denmark) to supply the enzymes and with DSM (Netherlands) for the genetically modified yeast.

Bioflex inaugurated in 2014 its first industrial plant of cellulosic ethanol with a production capacity of 80 million liters per year in São Miguel de Alagoas, Northeast of Brazil. This plant was purpose-built and not connected to a $1 \mathrm{G}$ plant. It uses straw as feedstock. Bioflex made an agreement with Usina Caeté of the Carlos Lyra Group to supply the straw and share a cogeneration facility. While collecting and transporting the straw to the plant proved to be a challenge, it was quickly resolved.

At first the strategy to import the technology was not very successful, as it faced several technical problems. The Betarenewable pretreatment technology revealed to be inadequate for sugarcane straw and bagasse. Since the beginning the plant operated well below its capacity. The main problem was the sand that came together with the straw. When submitted to the pretreatment high pressures and temperatures, it damaged the steel of the plant's valves, pumps and tubes. The percentage of sand in the straw was $8 \%$ rather than the required $2 \%$. However, the Proesa technology seemed also to face other problems with the kind of feedstock. With vapor explosion, bagasse and straw expanded very quickly, blocking the mechanical movement inside the reactor. The plant stopped its operations in 2016 but the company introduced important improvements in the process. In late 2018 , its founder declared that the main problems were fixed and that the company would produce 30 million liters of ethanol in 2019 [58].

Granbio's strategy was not restricted to cellulosic ethanol producing facilities, as it also aimed to become a producer of energy cane. Biovertix, the energy cane subsidiary, established a partnership with the University of Alagoas, Ridesa and IAC to develop new varieties of the plant. The University of Alagoas houses the Ridesa experimental station where it runs its variety crossbreeding program and has its

\footnotetext{
${ }^{8}$ The intention of the Granbio group was to install 8 industrial plants (4 cellulosic ethanol, 2 biochemistry, and 2 flexible biorefineries) by 2020, investing a total of 4 billion reals or US\$ 1,958 million [57]
} 
sugarcane genomic bank. This allowed Biovertix to develop new varieties.

Granbio also created a R\&D lab called Biocelere to address some of its new knowledge demands. This was located in Technopark, near UNICAMP and $\mathrm{CTBE}^{9}$-CNPEM, where the company could find important competences related to biotechnologies applied to the industrial process. The main focus was genetic enhancement of yeasts. This laboratory started operating in 2013 with 20 scientists, including $11 \mathrm{PhD}$ students, but was discontinued in 2017 due to financial problems faced by Granbio. Most of its staff went to CTBE-CNPEM and to UNICAMP.

The second important player in enzymatic hydrolysis was Raízen Energia S/A. This company was created in 2010 and is a joint venture between Cosan, the largest Brazilian sugarcane industrial group, and the fuel distribution arm of the Brazilian subsidiary of the Anglo-Dutch oil company Royal Dutch Shell. Raízen engaged in the building of a $2 \mathrm{G}$ hydrolysis plant connected to a $1 \mathrm{G}$ sugar and ethanol mill. The industrial plant started production in 2015 with a capacity of 44 million liters per year. The $2 \mathrm{G}$ technology came from the Canadian company Iogen, which was acquired by Royal Dutch Shell. The oil company's participation in Iogen $2 \mathrm{G}$ dated from 2002. In 2012, Iogen Energy became a joint venture between Raízen and Iogen Corporation. In order to adapt Iogen's $2 \mathrm{G}$ technology to sugarcane feedstock, Raízen sent sugarcane bagasse and straw for testing at the Iogen demonstration plant in Canada. The testing also involved Codexis, another Royal Dutch Shell company, which was in charge of developing the enzymes. At that time Iogen chose to install its first industrial plant in Brazil, using sugarcane bagasse and straw as feedstocks. In 2013, the first Iogen industrial plant was built near the city of Piracicaba, state of São Paulo, close to the Costa Pinto 1G sugar and ethanol mill. Thus, similar to Granbio, Raízen's strategy was to develop $2 \mathrm{G}$ technology based on an imported technology that was adapted to sugarcane bagasse and straw in a short period.

The same problems that emerged in the Bioflex plant also emerged in the Raízen plant. The quality of the feedstock did not meet the requirements of the enzymatic hydrolysis process. The main difficulties occurred in the pretreatment phase. Raízen is highly committed to overcoming the technological bottleneck but in the most recent harvest year of 2018-2019, the plant produced 16.5 million liters, around $37.5 \%$ of the plant's capacity [59].

The third plant was built by CTC (Centro de Tecnologia Canavieira), also in Piracicaba. CTC developed its own enzymatic hydrolysis process. The technology resulted from technological efforts made in the first decade of the century. CTC used a gradual strategy and started building a demonstration unit with a capacity of 3.5 million liters only. The plant, which started operating in 2015, also faced technological bottlenecks mostly related to the pretreatment phase and the high level of sand in the feedstock. CTC's strategy is not to become a producer of $2 \mathrm{G}$ bioethanol, but rather to sell its technology to other companies.

Unlike the Granbio group, neither Raízen nor CTC developed energy cane. However, a new company - Vignis - was created in 2011 with the goal of developing a new energy cane variety. This company has its roots in Canavialis, which was a start-up created during the last decade with the goal of developing new sugarcane varieties with conventional breeding methods. Canavialis was a spin-off of the Federal University of São Carlos. This company was bought by Monsanto in 2008. The American biotech company intended to open a new market. However, at the beginning of the decade, Monsanto gradually reduced its efforts in sugarcane and finally closed Canavialis. One of the main researchers at Canavialis, Sizuo Matsuoka, associated with a former employee of the Votorantim Investment fund, created Vignis.

Vignis was formed with the goal of developing and selling energy cane. Cellulosic ethanol was not the company's main target at first,

\footnotetext{
${ }^{9}$ CTBE (Bioethanol National Laboratory) changed its name to LNBR (Brazilian Biorenewables National Laboratory) in 2019.
}

since it believed that energy cane should be directly burned for steam and electricity generation. The company later on perceived that cellulosic ethanol was a very promising market since the fiber content of energy cane is at least twice that of regular sugarcane.

Vignis developed a different intellectual property strategy from main plant breeding programs like CTC, Ridesa and IAC, which commercialize plantlets and charge royalties for their reproduction by sugar mills. Vignis' strategy was to produce energy cane in large quantities and sell it to the mills. Vignis partnered with Raízen and Oderbrecht to sell energy cane and rented land to cultivate it. This strategy was not successful since its clients broke their long-term contracts, probably due to their own problems with cellulosic ethanol. In 2018, the company went bankrupt.

Besides these previous cases that launched and started their activities in $2 \mathrm{G}$ ethanol, there were several aborted initiatives. The main cases concerning cellulosic ethanol were Petrobras, Oderbrecht Agroindustrial and Abengoa.

Petrobras, the Brazilian state oil company, was a frontrunner in the development of cellulosic ethanol during the first decade of the century in Brazil. Its research center developed an important part of the hydrolysis process. However, at the beginning of the present decade, this company changed its strategy and partnered with the American company Blue Sugars Corporation to license its cellulosic ethanol technology. Petrobras invested in Blue Sugars Corporation to adapt its technology to Brazilian sugarcane bagasse and afterwards made an exclusive technology transfer agreement with the American company, which went bankrupt in 2013 [60]. Petrobras's intention was to build an industrial plant in the state of Goiás close to one of the company's mills, but the project was abandoned.

Oderbrecht Agroindustrial is the bioethanol arm of the Brazilian engineering and civil construction group Odebrecht that also owns Braskem, the largest national chemical group. Oderbrecht Agroindustrial owns several 1G sugarcane mills and intended to become successful in $2 \mathrm{G}$ technologies. The Brazilian company also chose a foreign partner, the Danish company Inbicon, to transfer cellulosic ethanol technology. Thus, Oderbrecht Agroindustrial made a licensing agreement with Inbicon in 2013, and samples of bagasse sugarcane feedstock were sent to Denmark to be tested in its pilot plant [60]. However, the decision to build a $2 \mathrm{G}$ industrial project was abandoned in spite of the $2 \mathrm{G}$ plant project being approved by the PAISS program ${ }^{10}$.

The third case was Abengoa. The Spanish company followed the strategy of Petrobras and Oderbrecht of acquiring $1 \mathrm{G}$ mills after the 2008 crisis. The strategy of this company was also to expand to $2 \mathrm{G}$ technologies. It inaugurated in 2014 a large cellulosic ethanol plant at Hugoton, Kansas, with a capacity of 95 million liters of ethanol, mainly using corn stove as feedstock. However, since 2015 the Spanish company has faced increasing financial problems and filed for bankruptcy in 2016. The American cellulosic ethanol plant was shut down in 2015 [61]. Abengoa also intended to build a 2G plant in Brazil. The Brazilian project was abandoned in spite of being approved by the PAISS program.

As we have shown above, entrepreneurial experimentation was dynamic, in both cellulosic ethanol and energy cane. Companies that were newcomers to the sugarcane industry but already established in the chemical or oil industry supported this system function. Also, many of these companies created strong ties with $1 \mathrm{G}$ sugar and ethanol mills.

\subsection{Knowledge development}

One of the main characteristics of the Brazilian system of innovation

\footnotetext{
${ }^{10}$ PAISS - a joint BNDES/FINEP plan to support innovation of sugarcane industry, launched by these two federal organizations in 2011 - was the main government decision to promote $2 \mathrm{G}$ in Brazil. More details about the resources and companies benefited will be shown in section 5.6 .
} 
is the prominent presence of academic research compared to corporate research. Only a few Brazilian companies actually do R\&D and patent their results [62]. This imbalance is also an issue in developed countries, like those in Europe, but is much more evident in the context of developing countries [63]. Therefore, the Brazilian bioethanol TIS revealed an important dynamism that was unequal according to the institutional nature of the actors and to the kind of knowledge that was created.

\subsubsection{Scientific knowledge}

Brazil has a prominent place in the creation of knowledge related to sugarcane at world level $[64,65]$. The country accounts for $29.1 \%$ of documents about sugarcane, far ahead of the US (11.6\%), Australia $(9.7 \%)$ and India $(7.4 \%)^{11}$. The main organizations responsible for this performance are the three state universities of the state of São Paulo (USP, UNESP and UNICAMP).

In cellulosic ethanol, Brazil's leadership is also impressive. The country ranks second worldwide with $15.9 \%$ of documents, behind the US (36\%) but ahead of China (11.6\%) and Canada (4.1\%). Among Brazilian organizations, the top three by order of importance are USP, UNICAMP and CNPEM. The first two are universities from the state of São Paulo, while CNPEM (National Research Center on Energy and Materials) is located near UNICAMP and has two important research areas related to bioethanol (CTBE) and biotechnologies (LNBio) (Table 3).

In energy cane we find a similar situation to cellulosic ethanol, although this field is more recent (Table 4). Brazil ranks second worldwide with $17.2 \%$ of publications on this subject. The main Brazilian universities are UNICAMP, UFPR and University of Viçosa. Granbio, which is at the head of the development of new varieties of energy cane, has cooperated with the Federal University of Alagoas, while Vignis established cooperation with UFSCAR and IAC. The last mentioned research institute is also engaged in the development of energy cane.

\subsubsection{Technological knowledge}

The presence of Brazilian actors in the creation of technological knowledge connected to cellulosic ethanol is limited. With the perspective of Brazil becoming a player in the field of cellulosic ethanol, foreign and multinational companies that were developing this technology started to file their applications with the Brazilian Patent Office. About $86.5 \%$ of all cellulosic ethanol patent applications in INPI were filed by foreign companies. The leader is the Danish company Novozymes, which holds a leading position as enzyme provider for hydrolysis process projects in Brazil (Table 5). This company played a major role in the development of dedicated enzymes for converting sugarcane bagasse into fermentable sugars in Brazil. Part of this effort was made in Brazil by its subsidiary in Curitiba [66]. As previously mentioned, Iogen, Inbicon and Beta Renewables were companies that developed and transferred enzymatic hydrolysis process technology to Brazilian partners. The Dutch company DSM had a similar position to Novozymes, mainly providing genetic engineered yeast for the fermentation process, particularly of pentose and xylose sugars.

Brazilian companies had a much more limited position in technological knowledge creation. The most important was Granbio, through its research laboratory Biocelere, located in Campinas. This company has filed 17 patents, almost all related to the development of new genetic engineered yeasts. It is followed by two universities (UNICAMP and UFAL) and by Petrobras and CTC. As mentioned before, Petrobras and CTC were developing their own enzymatic hydrolysis process, and CTC started a demonstration plant based on its own process in 2015.

The foreign companies transferred their technology to Brazil through partnerships with Brazilian companies, without in most of the

\footnotetext{
${ }^{11}$ The documents extracted from the Scopus base include articles, reviews and notes of scientific journals, conference papers and book chapters.
}

Table 3

Documents related to cellulosic ethanol in Brazil by the top 10 Brazilian research organizations (2007-2018).

\begin{tabular}{ll}
\hline & $\mathrm{N}^{\circ}$ Documents \\
\hline Brazil & 448 \\
USP (University of São Paulo) & 117 \\
UNICAMP (University of Campinas) & 101 \\
CNPEM (National Research Center on Energy and Materials) & 70 \\
UFSCAR (Federal University of São Carlos) & 39 \\
UFRJ (Federal University of Rio de Janeiro) & 35 \\
UNESP (São Paulo State University) & 34 \\
EMBRAPA (Brazilian Agriculture Research Organization) & 24 \\
University of Caxias do Sul & 24 \\
UFPR (Federal University of Paraná) & 23 \\
Federal University of Viçosa & 18 \\
\hline
\end{tabular}

Source: Scopus, 2018.

Table 4

Documents related to energy cane by Brazilian research organization (2006 to 2018).

\begin{tabular}{ll}
\hline & $\mathrm{N}^{\circ}$ of Documents \\
\hline Brazil & 26 \\
UNICAMP & 10 \\
UFPR & 7 \\
Federal University of Viçosa & 6 \\
IAC (Campinas Agronomic Institute) & 3 \\
Catarinense Federal Institute & 2 \\
Granbio & 2 \\
USP & 2 \\
UFSCAR & 2 \\
CTC & 2 \\
Vignis & 2 \\
\hline
\end{tabular}

Source: Scopus, 2018.

Table 5

Patent applications in INPI related to cellulosic ethanol (2005 to 2018).

\begin{tabular}{lll}
\hline Applicant Organization & \multicolumn{2}{c}{$\mathrm{N}^{\circ}$ of Patent Applications } \\
\cline { 1 - 2 } Name & Country & \\
\hline Novozymes & Denmark & 134 \\
Iogen & Canada & 50 \\
DSM & Netherlands & 28 \\
Inbicon & Denmark & 19 \\
Biocelere/Granbio & Brazil & 17 \\
Beta Renewables & Italy & 17 \\
IFP Energies Nouvelles & France & 6 \\
UNICAMP & Brazil & 5 \\
UFAL & Brazil & 5 \\
Petrobras & Brazil & 4 \\
CTC & Brazil & 3 \\
Flavio Ferreira/Erminio Rodrigues & Brazil & 3 \\
Rest & various & 36 \\
\hline
\end{tabular}

Source: Own elaboration based on INPI.

cases engaging in local technology development. The efforts related to the adaptation of the technology to local conditions were done at their home country or by subsidiaries located in developed countries.

For energy cane, Brazil has a much stronger position in terms of technology. All development of new varieties was done by Brazilian actors, mainly by the two companies previously mentioned and IAC. The only register about this activity was made by Granbio/Biovertis. As we stated before, this company established a collaboration with UFAL and Ridesa for the development of energy cane varieties. Between 2016 and 2017 it registered 9 varieties with the National Register of Cultivars of the Ministry of Agriculture named Vertix 1-9 [67]. Vignis, the other important player, did not use this system to register its varieties, and IAC, which has its own energy cane program, expects to launch its 
Table 6

Company publications (*) related to cellulosic ethanol in collaboration with Brazilian research organizations by partners (2007-2018).

\begin{tabular}{|c|c|c|c|c|c|c|c|c|c|}
\hline & Total & UFPR & USP & UNICAMP & UFRJ & University of Caxias do Sul & UNB & CNPEM & Others \\
\hline СТС & 11 & 6 & 3 & 1 & & 2 & & & 3 \\
\hline Petrobras & 6 & & & & 3 & & 2 & & 2 \\
\hline Fibria & 4 & 1 & 3 & 1 & & & & & \\
\hline VTT & 3 & 1 & 2 & & & & & 1 & 2 \\
\hline Syngenta & 2 & & & & & & & & 2 \\
\hline Granbio & 2 & & 1 & 1 & & & & & \\
\hline
\end{tabular}

Source: Scopus, 2018.

(*): only companies with more than one publication.

varieties commercially by $2024-2025$ [68].

In summary, the knowledge function of the Brazilian bioethanol TIS is oriented to scientific knowledge rather than to technological development. This is particularly true for cellulosic ethanol technology, where multinational companies dominate the field. However, in energy cane the technological knowledge of Brazilian actors is much stronger. When we look at the actors according to their institutional origin, we see that universities and some research centers play a prominent role, not only in scientific knowledge but also related to the creation of technological knowledge.

\subsection{Knowledge diffusion}

Since $2 \mathrm{G}$ knowledge and technologies were practically at their beginning, we could not observe many activities oriented towards knowledge diffusion in the Brazilian bioethanol TIS. Most of these activities happened in academia.

The main initiative in academia was the joint creation in 2014 of a graduate program in Bionergy by the three state universities of São Paulo (USP, UNICAMP and UNESP). This program, which is given in English, is dedicated to broaden and disclose Brazilian knowledge in $2 \mathrm{G}$ technologies to a larger public. It also intends to increase collaboration between the three main São Paulo universities that hold important competences related to sugarcane bioethanol. The CTBE/CNPEM researchers are also deeply engaged in this program through their partnership with UNICAMP.

The other important initiative in academia is the research network called BBEST (Brazilian Bioenergy Science and Technology Initiative). The network has already organized three conferences (2011, 2014 and 2017). In the last conference, 267 abstracts and papers were presented and the event was attended by more than 380 participants from 14 different countries. The event also offers awards for master's, PhD and post-doc academic works.

Another important international initiative is the BE-Basic Foundation (Biotechnology based Ecologically Balanced Industrial Consortium), a public-private partnership founded in 2010 and originally coordinated by Delft University of Technology. It started with a R\&D budget of 120 million euros and had an annual expenditure of 45 million euros per year. Brazil took part in it through the FAPESP BIOEN program. In 2012 Delft University opened an office in UNICAMP. Several PhD students were co-supervised by UNICAMP and Delft due to this collaboration.

The initiatives related to industry were much more limited. In 2016, the city of Piracicaba, where the Agronomic School of USP, CTC and Raízen are located, inaugurated the "Agriculture Silicon Valley." In spite of the engagement of many companies, very few have their focus on cellulosic ethanol. Raízen intends to expand its research activities, creating a start-up incubator. In Campinas, most of the initiatives related to start-ups and research companies happened in TechnoPark. However, most of them were abandoned, most notably Granbio Biocelere, which shut its research center after the great difficulties faced by $2 \mathrm{G}$ technologies since 2016 .

In 2014, ABBI (Brazilian Association of Industrial Biotechnology) was created with the goal of promoting a favorable economic, social and institutional environment for innovation in industrial biotechnology. Industrial biotechnology is understood as all industries that employ biomass and organic residues to produce chemical or energy products with the application of enzymes and microorganisms. This association gathers the main players in $2 \mathrm{G}$ ethanol and green chemistry in Brazil: Amyris, Basf, Braskem, DSM, Du Pont, Granbio, Novozymes, Raizen and Rhodia. Most of these companies are multinationals, but three of them are well-known national players. This association works like a lobby and a think-tank that suggests policies to the Brazilian government and congress.

Research networks between academia and research institutes and industrial companies engaged in development are an important aspect of how the TIS is operating. Nevertheless, the presence of companies in the creation of scientific knowledge is limited to 35 documents, which accounts for less than $10 \%$ of total documents (Table 6). CTC and Petrobras are the main players. However, the presence of the main industrial actors of the entrepreneurial function like Granbio is limited, while Raízen is completely absent. Only the best performing companies in terms of knowledge development engage in partnerships with universities.

Otherwise, technological research networks were less evident, even if there are strong ties between Brazilian companies, universities and research centers $[69,70]$. In order to map the existing network between these three main kinds of actors we specifically analyzed patent applications filed by Brazilian companies and related them to the origin of the inventors.

Table 7 shows that Brazilian universities and public research labs have contributed to Granbio and Petrobras technological development. Granbio located its research lab near UNICAMP in the city of Campinas, where part of the personnel came from. Granbio also established close links with the bioethanol research center (CTBE/CNPEM). The research activity developed in collaboration with the university was directed towards the development of genetic engineered microorganisms in the fermentation process. Petrobras, in turn, established close links with the Federal University of Rio de Janeiro, which collaborated in the development of the enzymatic hydrolysis process. In these two cases, geographic proximity was important for networking. However, CTC did not engage in any collaboration with Brazilian universities. This fact can be partially explained by the strong capabilities in bioethanol of this research center, which did not require outside technological knowledge.

Table 7

Participation of Brazilian academic researchers as inventors by institutional origin in patent applications filed by Brazilian companies in 2005-2018 (in number of patents).

\begin{tabular}{llllll}
\hline Company $\backslash$ Academic Institution & UNICAMP & CNPEM & UFRJ & UFPR & UFSC \\
\hline Granbio & 12 & 7 & & & \\
Petrobras & & 4 & & \\
CTC & & & & 1 & 1 \\
CPFL & & & & 1 \\
\hline
\end{tabular}

Source: Own elaboration based on INPI data. 


\subsection{Guidance of the search}

The lack of coordination between the numerous actors and stakeholders that are active in the innovation system is one of the main problems of the Brazilian innovation system [71,72]. This feature explains the absence of an organization that would endorse and promote specific sectoral policies, as in the case of $1 \mathrm{G}$ ethanol. The public policies related to bioethanol were created during a long-lasting process that started in the 1930s, when the government introduced the mixture of gasoline with sugarcane ethanol [73-76]. These policies went through important transformations in the 1990s, and CNE (National Energy Council) and ANP (National Petroleum Agency) became the main government organizations in charge of defining the ethanol-gasoline blend, price policy and taxes. This institutional set-up fits the requirements of $1 \mathrm{G}$ ethanol but is inadequate to promote a new technological system like $2 \mathrm{G}$ bioethanol.

Therefore, new organizations were important in this process. After the 2008 crisis that severely hit the sugarcane agroindustry, 2G technology became the new frontier that should enable this industry to recover growth [56,77-79]. New public actors increased their position in the transition of this system, defining new directions for the industry. These actors are mostly related to science, technology and innovation, like CGEE (Center of Strategic Management and Studies), FINEP (Brazilian Innovation Agency), BNDES (Brazilian Social and Economic Development Bank), FAPESP (São Paulo Research Foundation), and EPE

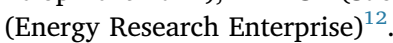

These organizations have published important studies and reports to show the attractiveness of $2 \mathrm{G}$ ethanol (see Table 8 ). These reports and particularly the BNDES report were very important to raise expectations about the profitability of $2 \mathrm{G}$ investments in Brazil. EPE developed the energy scenarios for ethanol expansion based on the commitments made by the Brazilian federal government at the Paris Conference in 2015. Among those commitments is the target of sustainable biofuels reaching $18 \%$ of the Brazilian energy mix by 2030 [80]. This target was quite modest since in 2015 this share was already $17.9 \%$. However, as the Brazilian economy and energy supply were supposed to increase, the goal created a perspective of expansion that materialized in EPE scenarios.

In addition, the private sector created very positive expectations about the evolution of $2 \mathrm{G}$ bioethanol in Brazil. In 2013, Granbio announced a production target of 1 billion liters of cellulosic ethanol in 2020 and Raízen communicated similar expectations: to build 8 cellulosic industrial plants by 2024 and reach the mark of 1 billion liters per year [81]. Other companies like Petrobras, Oderbrecht and Abengoa expected at that time also to install cellulosic ethanol plants in Brazil.

This positive view of companies about $2 \mathrm{G}$ future development certainly influenced the behavior of the government, especially BNDES and FINEP, in the promotion of important policy initiatives. The PAISS program stimulated the production of $2 \mathrm{G}$ bioethanol, new sugarcane products, including chemical bioproducts, and sugarcane gasification technologies $[82,83]$. This was an important step, but it was not enough to provide clear guidance on how this transformation of the bioethanol innovation system should happen.

\subsection{Market formation}

One of the main failures of the Brazilian energy policy was the lack of a niche market for cellulosic ethanol. This is an important issue since $2 \mathrm{G}$ ethanol has higher production costs than $1 \mathrm{G}$ ethanol [56]. The market policies were all tailored to $1 \mathrm{G}$ ethanol. They consisted in a mandatory blend of ethanol and gasoline and a differentiated tax on

\footnotetext{
${ }^{12}$ Only EPE belongs to the Ministry of Energy; CGEE and FINEP belong to the Ministry of Science and Technology, BNDES to the Ministry of Industry, and FAPESP to the state of São Paulo.
}

ethanol against gasoline. These policies lost their effectiveness at the beginning of the decade, when the federal government capped gasoline prices revoking the tax difference with ethanol [84]. Nevertheless, even after the renouncement of this price policy in the middle of decade, bioethanol continued to lost market share compared to gasoline ${ }^{13}$.

Worrying that bioethanol was losing share in the Brazilian energy mix, and in order to attain the Paris Conference targets, the Brazilian Government launched the Renovabio Policy (law $n^{\circ} 13,576$ of December 2017). This policy sets $\mathrm{CO}_{2}$ emission targets for hydrocarbon fuel distributors, using biofuels as the main instrument to accomplish these emission goals. Biofuel producers will receive Efficient Biofuel Production Certification that will allow them to sell Decarbonization Credits (CBIO) to fuel distributors [86]. For the first time since the Proalcohol program, we can observe a demand target set by the Brazilian government for biofuels through the mechanism of $\mathrm{CO}_{2}$ emission certificates.

However, this target is quite imprecise in terms of additional production of bioethanol. This is why EPE [85] worked with three scenarios where biofuel supply and demand can vary, mostly according to the effectiveness of supply and demand incentives of biofuels compared to fossil fuels. According to these scenarios biofuel production by 2030 would increase by a range of 7.6 billion liters to 15.7 billion liters compared to the 2017 level. However, in these scenarios $2 \mathrm{G}$ ethanol has a fixed target of 2 billion liters by 2030 , which is not supported by any specific market mechanism.

Therefore, one important downside of the new Brazilian decarbonization policy is the lack of a specific demand instrument to enforce $2 \mathrm{G}$ biofuels. The Renovabio policy, in spite of the great expectation, is not addressing this issue. This fact cannot be explained by a poor understanding of the main Brazilian actors about the needs of a transition policy for $2 \mathrm{G}$ ethanol. The BNDES report [56] clearly stated that one of the main aspects of a $2 \mathrm{G}$ policy in Brazil, following particularly the US experience, should be the establishment of a mandatory fraction of $2 \mathrm{G}$ ethanol, estimated at $0.25 \%$ of the mandatory blend of ethanol in gasoline. The ABBI report [87] also recommends that the Brazilian government grant cellulosic ethanol a tax abatement premium of $\mathrm{R} \$ 1$ / liter for liquid fuel distributors in the special gasoline tax called CIDE (Contribution for Intervention in the Economic Domain) until Brazilian cellulosic ethanol production reaches 2.5 billion liters/year.

\subsection{Resource mobilization}

The first actor to engage in the funding of scientific and technological $2 \mathrm{G}$ research was FAPESP. This research foundation of the state of São Paulo, where the main actors of the sugarcane industry are located, created the BIOEN program in 2008 in order to promote bioenergy in Brazil, with its main focus on sugarcane bioethanol. The program encompasses five main areas: biomass for bioenergy; production of biofuels; biorefineries and biochemistry; application of bioethanol to motors including fuel cells; environmental and socioeconomic impacts. Since BIOEN was launched, 220 research projects have been concluded (Table 9). The leading research organizations involved were, by order of importance, USP, UNICAMP, and UNESP, followed by APTA, which mainly includes IAC, and ABTLUS, which concerns CNPEM. One of the FAPESP funding lines favors industry and academia cooperation. The main companies that co-funded academia projects belonged to chemical sector and were interested in biochemistry, such as Braskem and Oxiteno, while one company, ETH Energia (Odebrecht), was concerned with cellulosic ethanol ${ }^{14}$.

\footnotetext{
${ }^{13}$ The share of bioethanol in car consumption dropped from $38.4 \%$ to $34.3 \%$ between 2010 and 2017, while gasoline increased from $56 \%$ to $61.4 \%$ in the same period. The remaining share is supplied by compressed natural gas [85].

${ }^{14}$ Fapesp funded in 2002 a cellulosic ethanol demonstration plant project executed by Dedini. This company used organosolv, an acid hydrolysis process,
} 
Table 8

Main reports on $2 \mathrm{G}$ ethanol and sugarcane.

\begin{tabular}{|c|c|}
\hline Organization & Title and year \\
\hline BNDES & $\begin{array}{l}\text { - From promise to reality: how cellulosic ethanol can revolutionize the sugarcane industry - an evaluation of competitive potential and public policy } \\
\text { suggestions. BNDES Setorial, } n^{\circ} 41,2015 \text {. }\end{array}$ \\
\hline CGEE & - Second-generation sugarcane bioenergy \& biochemicals - advanced low-carbon fuels for transport and industry. Brasília, 2017. \\
\hline EPE & - Ethanol supply and Otto cycle demand for 2018-2030. Brasília, 2018. \\
\hline FAPESP & - Souza et al. (eds.) - Bioenergy \& sustainability: bridging the gaps. São Paulo, 2015. \\
\hline ABBI & - The contribution of industrial biotechnology to Brazilian development: the potential of second-generation ethanol and the levers for its viability. Brazil, 2016 . \\
\hline
\end{tabular}

Table 9

FAPESP BIOEN research projects concluded by the main research organizations (2008-2018).

\begin{tabular}{|c|c|c|c|c|c|}
\hline & $\begin{array}{l}\text { Thematic } \\
\text { Projects }\end{array}$ & $\begin{array}{l}\text { Regular } \\
\text { Projects }\end{array}$ & $\begin{array}{l}\text { Young } \\
\text { Researcher } \\
\text { Projects }\end{array}$ & $\begin{array}{l}\text { University - } \\
\text { Industry } \\
\text { Projects }\end{array}$ & $\begin{array}{l}\text { Total } \\
\text { BIOEN }\end{array}$ \\
\hline Universities & 31 & 113 & 21 & 15 & 220 \\
\hline - USP & 15 & 41 & 7 & 7 & 70 \\
\hline - UNICAMP & 6 & 21 & 5 & 2 & 34 \\
\hline - UNESP & 1 & 22 & 2 & 1 & 26 \\
\hline - APTA & 3 & 9 & 1 & & 13 \\
\hline - ABTLUS & 2 & 5 & 3 & 1 & 11 \\
\hline - UFSCAR & & 4 & 1 & 1 & 6 \\
\hline - UFABC & & 3 & 1 & & 4 \\
\hline - Others & 3 & 5 & & 3 & 11 \\
\hline \multicolumn{6}{|l|}{ Companies (*) } \\
\hline - Braskem & & & & 5 & 5 \\
\hline - Vale & & & & 3 & 3 \\
\hline - Oxiteno & & & & 3 & 3 \\
\hline - ETH Energia & & & & 1 & 1 \\
\hline - Mahle & & & & 1 & 1 \\
\hline - Microsoft & & & & 1 & 1 \\
\hline
\end{tabular}

(*): partner companies in University - Industry Projects.

Source: Based on FAPESP.

BNDES and FINEP played the main role in the promotion of cellulosic ethanol during the present decade. These two federal innovation funding agencies engaged deeply in the promotion of enzymatic hydrolysis in Brazil, mostly through the PAISS program. The volume of funds allocated to PAISS was estimated around $\mathrm{R} \$ 3$ billion. The program issues two main calls. The first in 2013 was dedicated to industrial processes while the second in 2014 had a wider scope including agriculture technologies, called "PAISS Agrícola."

The PAISS program was the main catalyst of $2 \mathrm{G}$ technologies in Brazil (Table 10). The program had a wider scope than biofuels. An important part of it was directed to biochemistry based on sugarcane. However, the leading component was directed to cellulosic ethanol. The PAISS program funded the main players related to cellulosic ethanol. The execution period of the projects - between 2013 and 2016 - coincides with the launching of the main cellulosic ethanol industrial and demonstration projects. Most of the resources were allocated to the companies through reimbursable funds with low interest rates ${ }^{15}$. However, BNDES acquired important equity participation in Granbio and CTC. Granbio was the main taker of BNDES funds, while CTC received the greatest amount of FINEP funds. Raízen, which is an important player in the $2 \mathrm{G}$ ethanol, also received important financial support from BNDES, but outside the PAISS program. Other firms like Abengoa and Odebrecht, which intended to install cellulosic ethanol industrial plants but abandoned their projects, were also funded by the PAISS program. Vignis was also marginally funded by BNDES, but Biovertis and Biocelere, all belonging to Granbio, received significant

(footnote continued)

to produce ethanol from sugarcane bagasse [88].

${ }^{15}$ The figures concern contracted but not necessarily disbursed reimbursable and non-reimbursable funds.
Table 10

Funds allocated by FINEP and BNDES to the PAISS Program (2 phases).

\begin{tabular}{|c|c|c|c|c|}
\hline Company & $\begin{array}{l}\text { FINEP (R\$ } \\
\text { thousand) }\end{array}$ & Funding (*) & $\begin{array}{l}\text { BNDES (R\$ } \\
\text { thousand) }\end{array}$ & Funding $(*)$ \\
\hline Abengoa & 76,680 & $\mathrm{R}$ & 286,307 & $\mathrm{R}$ \\
\hline Amyris & 6,435 & $\mathrm{R}$ & 74,353 & $\mathrm{R}$ \\
\hline Antoniosi & & & 12,127 & $\mathrm{R}$ \\
\hline Barauna & 2,800 & $\mathrm{R}$ & & \\
\hline Biomm & 3,132 & NR & & \\
\hline $\begin{array}{l}\text { Biocelere } \\
\quad \text { (Granbio) }\end{array}$ & 10,000 & NR & 4,667 & $\mathrm{R}$ \\
\hline Bioflex (Granbio) & & & 300,295 & $\mathrm{R}$ \\
\hline $\begin{array}{l}\text { Biovertis } \\
\qquad \text { (Granbio) }\end{array}$ & & & 12,350 & $\mathrm{R}$ \\
\hline Granbio & 135,126 & $\mathrm{R}$ & 649,591 & $\mathrm{E}$ \\
\hline СТC & 37,378 & NR & 236,766 & $\mathrm{E}$ \\
\hline СТC & 227,583 & $\mathrm{R}$ & 72,676 & $\mathrm{R}$ \\
\hline Dow Brasil & 2,877 & NR & 21,239 & $\mathrm{R}$ \\
\hline Geo Energética & 161,709 & $\mathrm{R}$ & & \\
\hline Oderbrecht & 8,309 & NR & 464,364 & $\mathrm{R}$ \\
\hline PHB & & & 9,131 & $\mathrm{R}$ \\
\hline Raízen Energia(1) & & & 207,762 & $\mathrm{R}$ \\
\hline São Martinho & 133,780 & $\mathrm{R}$ & 95,210 & $\mathrm{R}$ \\
\hline Solazymes & 5,800 & NR & 245,699 & $\mathrm{R}$ \\
\hline Vignis & & & 4,891 & $\mathrm{R}$ \\
\hline VTT & 9,985 & NR & & \\
\hline
\end{tabular}

$(*): \mathrm{R}=$ reimbursable funds; $\mathrm{NR}=$ non-reimbursable funds; $\mathrm{E}=$ equity participation

(1): Raízen received a loan in the FINEM Program for its $2 \mathrm{G}$ plant.

Source: Based on FINEP and BNDES figures.

amounts for energy cane development.

\subsection{Creation of legitimacy}

Support for the local development of new technologies by organized groups of society, especially in industry, is usually deficient in developing countries, even in Brazil $[44,89,90]$. In the case of the sugarcane industry, there is strong organized support for these activities by society. UNICA (Brazilian Sugarcane Industry Association) is a wellknown association that has strong influence in political decisions concerning bioethanol in Brazil [91]. However, its engagement to lobby for $2 \mathrm{G}$ technologies was limited because of its well-established interests connected to $1 \mathrm{G}$ technologies.

The leading $2 \mathrm{G}$ promoters are mostly academia and funding agencies like FAPESP and BNDES. These actors perceived the opportunity offered by $2 \mathrm{G}$ technologies and the role they could play in the future expansion of the sector. The academic report prepared for CGEE placed cellulosic ethanol as a key technology to reach the production targets of the following 20 years [10].

The attention of Brazilian society, industrial interest groups, and even the government at federal and state level was mainly related to the capacity of academia to raise interest about the opportunities offered by $2 \mathrm{G}$ technologies. The involvement of federal funding agencies in support of the PAISS program and the positive expectations of the industry about the development of these technologies in Brazil were very important to create a certain momentum, which is clearly revealed by the 


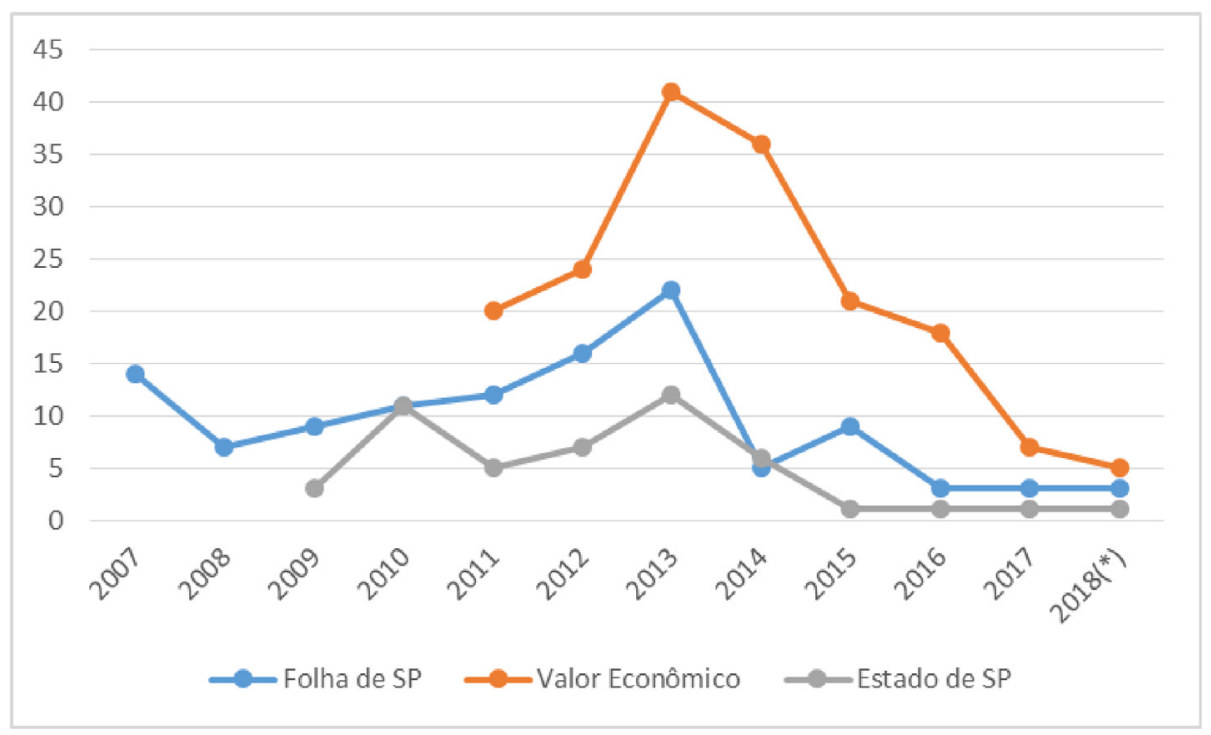

Fig. 2. Articles about 2G Ethanol in three main national newspapers. (*): until October 2018.

peak in 2013 of the number of articles in the Brazilian press (Fig. 2).

The surge of press interest in $2 \mathrm{G}$ technologies happened when the PAISS program was launched. These articles were mainly very optimistic concerning the possibilities of $2 \mathrm{G}$ technologies in Brazil, reproducing the discourse of academia and industry. The perspective was that $2 \mathrm{G}$ ethanol would become immediately competitive in relation to $1 \mathrm{G}$ ethanol and gasoline. When $2 \mathrm{G}$ ethanol started to show difficulties in its operation, the interest of the press decreased and the articles started to become more skeptical about the perspectives in Brazil. The institutional changes proposed by BNDES and ABBI were not even commented in the press, revealing a lack of interest in discussing the additional costs related to the introduction of this new technology.

\section{Timeline of the Brazilian bioethanol TIS}

The starting point of the Brazilian bioethanol TIS came from academia. The CGEE report [10], which called attention to the great potential of expansion of Brazilian ethanol production, had a great impact at federal and São Paulo state decision levels. This report clearly linked this potential to a leap of the Brazilian bioethanol TIS to 2G technologies and influenced the creation of the CTBE-CNPEM biofuel research center close to UNICAMP in 2010.

The F7 function of creation of legitimacy started operating quite well under the influence of the academic actor, which was allied to São Paulo and federal organizations related to innovation. This function influenced the F6 function of resource mobilization with the creation of Fapesp's Bioen program and other federal funds [17] that were key to the expansion and consolidation of F2 - creation of knowledge. A new actor, CTBE-CNPEM, which improved knowledge creation, was important to consolidate $2 \mathrm{G}$ technologies in the Brazilian Biethanol TIS. As we have already shown, F2 was performing well, placing Brazil as a worldwide leader in knowledge creation related to $2 \mathrm{G}$ ethanol.

Therefore, in the first phase the science and technology push was the main driver [28]. However, creation of knowledge was much greater in the scientific than in the technological area. The number of published scientific documents related to cellulosic ethanol increased dramatically since the middle of the last decade, showing the importance of these initiatives to increase performance in the scientific area (Fig. 3). Some industrial players also engaged in efforts to create local knowledge at the industrial level. CTC and Petrobras started to develop their own cellulosic hydrolysis processes.

A second phase comes when federal actors, especially BNDES, decided to engage more unequivocally in the introduction of $2 \mathrm{G}$ technologies in the Brazilian market (F6). The main initiative of this new phase was the launch of the PAISS program. The engagement of industry increased significantly (F1) with the launch of two cellulosic ethanol industrial plants and one demonstration plant. However, in the technological knowledge creation function (F2), we could notice a clear dominance of foreign companies. Thus, in this second phase an entrepreneurial function started to work but disconnected from the local knowledge base.

The federal government's strategy to leapfrog into $2 \mathrm{G}$ technologies faced important challenges. Therefore, this strategy was unable to constitute a dynamic where all seven system functions worked together [28]. While it was certainly successful to a certain extent within resource mobilization (F6), it revealed several weaknesses in other important functions.

As a result of the lack of coordination between federal public actors, particularly between BNDES and the Ministry of Science and Technology and Ministry of Mines and Energy, no coherence was provided to the function of guidance of the search (F4). The poor coordination and the lack of a coherent long-term view of the main actors hindered the creation of a clear path for cellulosic ethanol in the Brazilian energy mix.

The poor performance of the guidance of the search function (F4) was also followed by a feeble performance of the market function (F5). The lack of a niche market for cellulosic ethanol separated from the well-established $1 \mathrm{G}$ ethanol was one of the main weakness of the Brazilian policy mix. Even if this solution was already known by the main public actors and, to some extent, requested by the main industrial actors, it did not find its way into the Brazilian energy policy.

One of the main reasons for the poor F4 and F5 performance is the weak support for new technologies outside academia related to the creation of legitimacy function (F7). This support seems only to happen if the new technology is already performing equally to or better than the incumbent technology. When it became clear that a learning period estimated at over 5 years was necessary, the public opinion represented by the press almost lost its interest in the new technology and became much more critical about its perspectives.

\section{The role of context}

The decisions to develop $2 \mathrm{G}$ in Brazil, specifically of cellulosic ethanol, were strongly motivated by investments in the global TIS made by developed countries, particularly in the US and Europe. Since 1994, with the implementation of the Biofuels System Program of the US 
350

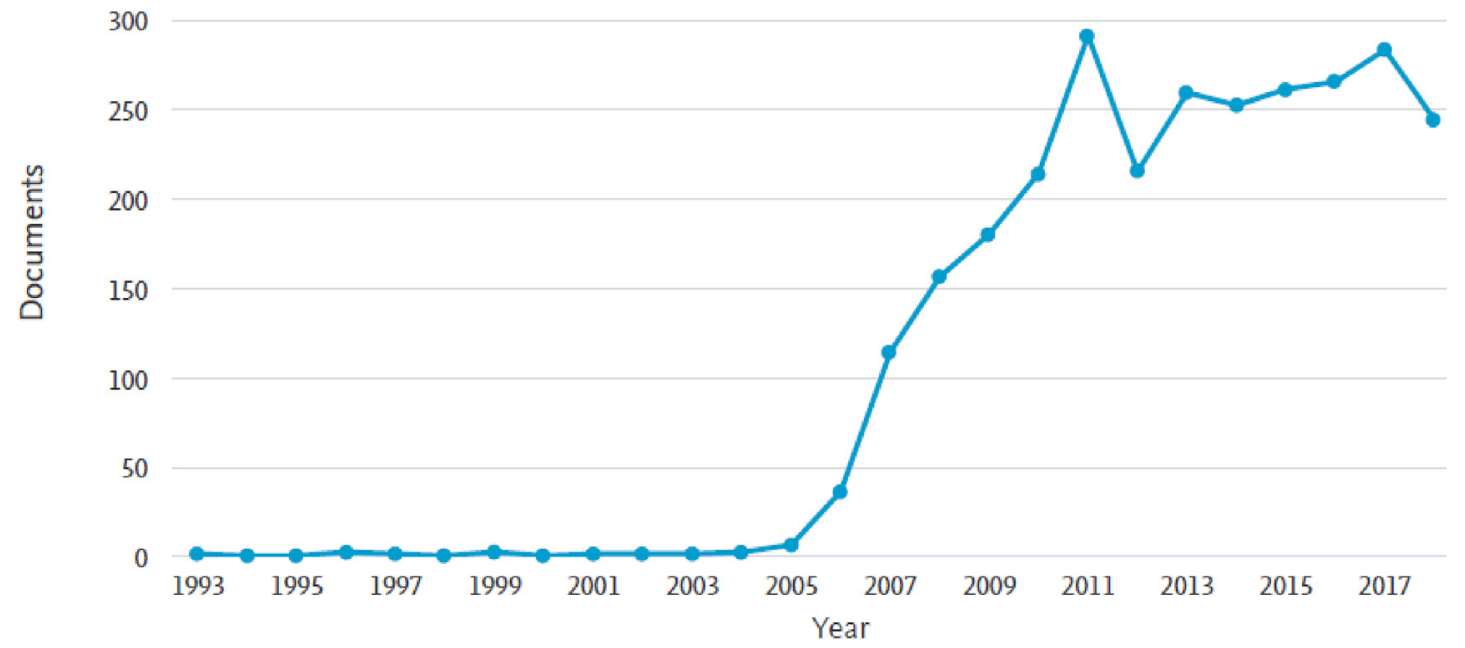

Fig. 3. Brazilian documents related to cellulosic ethanol until 2018 (search date March 28, 2019). Source: Scopus.

DOE, there has been a structured policy to develop $2 \mathrm{G}$ technologies in that country. The Renewable Fuel Standard 2005/2007 was a turning point in this policy, associating the supply-side policy of DOE with the demand-side policy of EPA [92]. The Energy Independence and Security Act of 2007 (EISA) fixed aggressive goals for second-generation bioethanol by 2022 [93]. In 2016, BETO considered that cellulosic ethanol was a completely established technology in the US by 2015 with a production capacity of 333 million liters/year [94].

Nevertheless, the actor's positive vision of the US was not borne out by the facts. Important industrial project plants were closed, like Abengoa, or sold out, like Dupont [95]. The production of cellulosic ethanol was only 38 million liters/year in 2017 [92], well below the intended EISA target fixed at 60.5 billion liters/year by 2022 . Moreover, only half of the liquid cellulosic ethanol used to comply with RFS in 2017 was produced domestically [93]. Many technical problems were faced by the US and by several industrial plants in other leading countries. The Beta Renewables Crescentino Industrial Plant was shut down with the bankruptcy of the Mossi \& Ghisolfi Group. These cases are not isolated and several cellulosic industrial plants faced serious problems to function properly ${ }^{16}$. Thus, the technological difficulties were underestimated when cellulosic ethanol was scaled up [96]. Technical problems very similar to those described for the Brazilian plants happened worldwide.

The other important contextual factor is the evolution of the Brazilian economy. The Brazilian economy grew consistently from 2004 to 2013. Nevertheless, from 2014 on Brazil faced a very deep economic crisis. This general context influenced the innovation policies driven by the government in the two periods. BNDES broadened its scope of action including innovation alongside investment and capital funding, which were its usual mechanisms of action, by offering non-reimbursable innovation funds (Funtec - Science and Technology Development Fund) in 2006 [98]. In 2008, the government engaged in a countercyclical economic policy because of the world economic crisis. Due to this policy, BNDES dramatically increased its funding for Brazilian development. The PAISS program launched in 2011 was a clear consequence of this new drive of Brazilian economic policy. However, the changes in the Brazilian economy came right after Dilma Roussef's re-election in 2014 and became evident after her impeachment in 2016. The real monthly outlay of the bank dropped more than three times

\footnotetext{
${ }^{16}$ A study conducted for the European Commission by a consultancy company revealed that less than $1 \%$ of project capacity was effectively working [97].
}

between 2014 and 2017, approaching in 2018 the level reached in 2005 (Fig. 4.).

The change in economic policy generated a deep setback in federal government policy for the promotion of $2 \mathrm{G}$ in Brazil. The behavior of private funding followed the same path and new investments in innovation were practically discontinued.

\section{Conclusion}

We have shown that the transition towards $2 \mathrm{G}$ technologies of the Brazilian bioethanol TIS is not an easy process to organize. Brazil did well in building a strong scientific base and implementing important industrial projects. The system function of resource mobilization (F6) was quite impressive and positioned Brazil in the international 2G scene. However, there were important missing links. The strong dependence on foreign technology was inappropriate for local conditions (F1). The knowledge creation function (F2) was well developed but unevenly distributed between the scientific and technological areas, benefitting the scientific area. The function of guidance of search (F4) was weak because a clear perspective was missing. Furthermore, the federal government did not create a stable niche market for the start of this technology, revealing a weak market formation function (F5). The legitimation function (F7) also proved to be deficient due to the poor engagement of the media in explaining the need for a transition period in the consolidation and establishment of the new technology.

The weak entrepreneurial function (F1), the unbalanced knowledge creation (F2) in benefit of the scientific area, the lack of coordination among main actors (F4), the absence of a niche market (F5), and the weak advocacy coalition towards new technologies (F7) are clear features of fragile innovation systems ${ }^{17}$. Therefore, there was no systemic drive, with all seven functions neither operating together nor reinforcing each other.

The case study showed that the bioethanol innovation system in Brazil has some typical characteristics of innovation systems in developing countries, like the strong dependence on foreign technology and unfavorable macro-economic conditions. On the other hand, we have also shown that Brazil has a global leading position in academic

\footnotetext{
${ }^{17}$ These features are aligned with the general characteristics of the systemic failures of the developing countries' national innovation systems stated as "the inability of a system of innovation to support the creation, absorption, retention, use and dissemination of economically useful knowledge through interactive learning or in-house R\&D investments" [50, p. 361)
} 


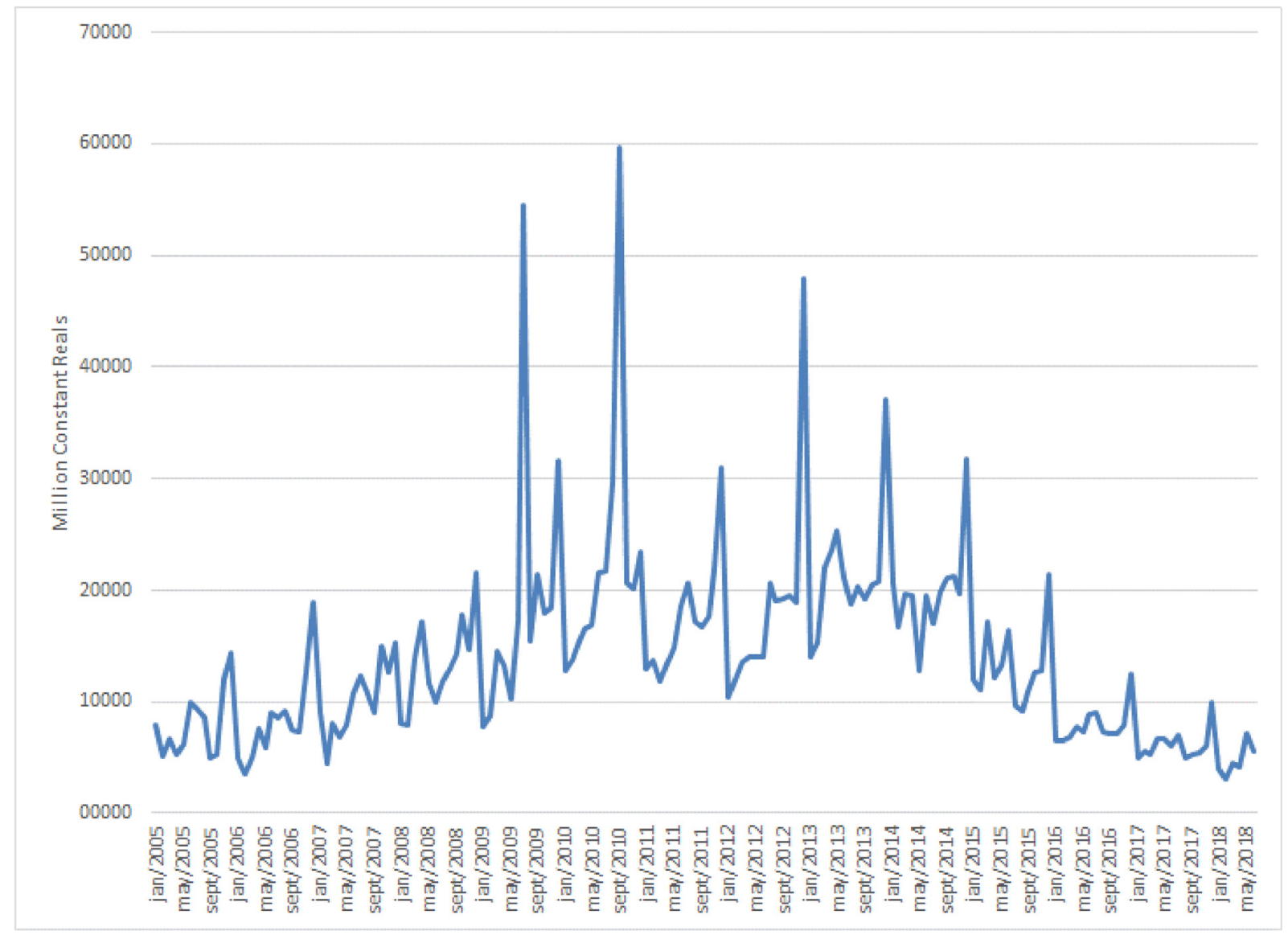

Fig. 4. BNDES monthly outlays (June 2018 constant reals*). *: 1 US $\$=3.85$ Reals. Source: BNDES Sectoral Series June 2018.

knowledge and the absorptive capacity to work with high-tech foreign partners.

Policy makers in Brazil have based their policy excessively on the linear model of innovation by investing in knowledge development and some demonstration projects. A broader innovation systems perspective was lacking and proved to slow down the transition process. Much more attention should have been given to guidance of the search (creating joint road maps for $2 \mathrm{G}$ ethanol, creating joint visions about the future of the Brazilian ethanol industry) and to the creation of a market for $2 \mathrm{G}$ ethanol. The latter was especially detrimental to economically viable business cases. Furthermore, the Brazilian government should have been sensitive to the resistance to change in Brazilian society, especially the concern about rising costs. Political leadership is necessary to sketch future scenarios that go beyond a short period of increasing costs and depict a future where Brazil could be a world leader in the production of sustainable and affordable bioethanol.

A systems perspective alone may not be enough when the innovation system is highly dependent on its context. At the beginning of the decade that context seemed to be very positive as $2 \mathrm{G}$ was supposedly approaching the industrial level and was ready to be disseminated. Despite these positive expectations, the reality proved to be more complex, revealing the important role of uncertainty in the innovation process. On top of this, the macroeconomic context of the Brazilian economy changed negatively in the middle of the decade. The consequence is that developments lagged behind initial expectations. This is also a typical feature of technological transition processes. A longterm view and consistent long-term policies are required to deal with inevitable periods of slow progress. This is a key challenge for policy makers all over the world who like to see measurable progress in their political lifetime.

\section{Declaration of Competing Interest}

The authors declare that they have no known competing financial interests or personal relationships that could have appeared to influence the work reported in this paper.

\section{Acknowledgements}

The first author would like to acknowledge the financial support received from the São Paulo Research Foundation (FAPESP), Brazil (grant: 2017/03407-5). The authors would also like to thank the anonymous reviewers and the editor for their valuable comments and suggestions made on the earlier versions of this papers.

\section{References}

[1] IEA (International Energy Agency), Key World Energy Statistics 2018, OECD/IEA, Paris, 2018. https://webstore.iea.org/key-world-energy-statistics-2018.

[2] J. Goldemberg, S.T. Coelho, Renewable energy-traditional biomass vs. modern biomass, Energy Policy 32 (2004) 711-714.

[3] I.T. Santos, Confronting governance challenges of the resource nexus through reflexivity: across-case comparison of biofuels policies in Germany and Brazil, Energy Res. Social Sci. 65 (2020) 1014642, https://doi.org/10.1016/j.erss.2020.101464.

[4] T. Searchinger, R. Heimlich, R. A. Houghton, F. Dong, A. Elobeid, J. Fabiosa, S. Tokgoz, D. Hayes and T.-H. Yu, Use of U.S. Croplands for Biofuels Increases Greenhouse Gases Through Emissions from Land Use Change, Science Express Report, 2008. www.sciencexpress.org / 7 February 2008 / Page 2 / 10.1126/science. 1151861

[5] D. Pimentel, T.W. Patzek, Ethanol Production Using Corn, Switchgrass, and Wood Biodiesel Production Using Soybean and Sunflower, Nat. Resour. Res. 14-1 (2005) 65-76, https://doi.org/10.1007/s11053-005-4679-8.

[6] P. Ramos, O trabalho na lavoura canavieira paulista: evolução recente, situação atual e perspectivas, in: C. Miranda e B. Tibúrcio (Org.), Emprego e Trabalho na Agricultura Brasileira, IICA, Brasília, 9 (2009) 304-325. ISBN: 13.978-92-9039990-2. 
[7] A.T. Furtado, L.A. Cortez, M.G. Felipe, R. Rossetto, P.S. Magalhães, M.R. Leal, Diretrizes para uma Política do Estado de São Paulo de Pesquisa, Desenvolvimento e Inovação do Etanol, in: L.A. Cortez (Coord.), Bioethanol de Cana-de-Açúcar - P\&D para Produtividade e Sustentabilidade, São Paulo, Blucher, 2010, pp. 937-950. ISBN: 978-85-212-0531-9.

[8] G. Verbong, D. Lorbach, Introduction, in: G. Verbong, D. Lorbach (Eds.), Governing the Energy Transition, Reality, Illusion or Necessity? Routledge, London \& New York, 2012, pp. 1-23.

[9] EPE (Energy Research Enterprise), Brazilian Energy Balance 2018 Year 2017, Empresa de Pesquisa Energética, Rio de Janeiro, 2018.

[10] CGEE (Center for Strategic Studies and Management), A Study about the Possibilities and the Impacts of Great Volumes of Ethanol Production to Substitute partially Gasoline in the World - Phase 2 - Final Report. CGEE, Brasília, March 2007. https://www.cgee.org.br/estudoscgee.

[11] G.M. Souza, R.L. Victoria, C.A. Joly, L.M. Verdade (Eds.), Bioenergy \& Sustainability: bridging the gaps, FAPESP, São Paulo, 2015http://bioenfapesp.org/ scopebioenergy/index.php/chapters.

[12] UNICA (Brazilian Sugarcane Industry Association), 2019. Unicadata. http://www. unicadata.com.br/historico-de-producao-e-moagem.php?idMn $=31 \&$ tipoHistorico $=2$. (Accessed 15 February 2019).

[13] Biomass Research and Development Board, The Bioeconomy Initiative: Implementation Framework, DOE/USDA, 2019. https://biomassboard.gov/pdfs/ Bioeconomy_Initiative_Implementation_Framework_FINAL.pdf.

[14] J. Philp and D. Winickoff, Innovation Ecosystmes in the Bioeconomy, OECD Science, Technology and Industry Policy Papers, OECD Publishing, No. 76, Paris, September 2019.

[15] IEA (International Energy Agency), Technology Roadmap, Delivering Sustainable Bioenergy, OECD/IEA, Paris, 2017.

[16] S. Silveira, F.X. Johnson, Navigating the transition to sustainable bioenergy in Sweden and Brazil: Lessons learned in a European and International context, Energy Res. Social Sci. 13 (2016) 180-193, https://doi.org/10.1016/j.erss.2015.12.021.

[17] A.T. Furtado, M.I.G. Scandiffio, L.A.B. Cortez, The Brazilian sugarcane innovation system, Energy Policy 39 (2011) 156-166, https://doi.org/10.1016/j.enpol.2010. 09.023.

[18] J. Schumpeter, The theory of Economic Development (An Inquiry into Profits, Capital, Credit, Interest and Business Cycle), Harvard University, translated from the German, First Edition in German, 1911.

[19] C. Freeman, Technology Policy and Economic Performance, Lessons from Japan, Pinter, London, 2007.

[20] R.R. Nelson A Retrospective, in: R.R. Nelson (ed.) National Innovation Systems: A Comparative Analysis, Oxford University Press, Oxford, pp. 505-523, 1993.

[21] C. Freeman, C. Perez, Structural crisis of adjustment, business cycle and investment behavior, in: G. Dosi, C. Freeman, R. Nelson, G. Silverberg, L. Soete (Eds.), Technical Change and Economic Theory, Pinter Publishers, London and New York, 1988, pp. 38-66.

[22] B. Carlsson, R. Stankiewicz, On the nature, function, and composition of technological systems, J. Evol. Econ. 1 (1991) 93-118.

[23] S. Jacobsson, A. Johnson, The diffusion of renewable energy technology: an analytical framework and key issues for research, Energy Policy 28 (2000) 625-640.

[24] B. Carlsson, S. Jacobsson, M. Holmén, A. Rickne, Innovation systems: analytical and methodological issues, Res. Policy 31 (2002) 233-245.

[25] S. Jacobsson, A. Bergek, Transforming the energy sector: the evolution of technological systems in renewable energy technologies, Ind. Corporate Change 13 (2004) 815-849.

[26] A. Bergek, M. Hekkert, S. Jacobsson, Functions in innovation systems: A framework for analyzing energy system dynamics and identifying goals for system-building activities by entrepreneurs and policymakers, in: T.J. Foxon, J. Kohler, C. Ougton (Eds.), Innovation for a Low Carbon Economy. Economic, Institutional and Management Approaches, Edwards Elgar, Cheltenham, UK and Northampton, MA, USA, 2008.

[27] M.P. Hekkert, R.A.A. Suurs, S.O. Negro, S. Kuhlmann, R.E.H.M. Smits, Functions of innovation systems: a new approach for analyzing technological change, Technol. Forecast. Soc. Chang. 74 (2007) 413-432, https://doi.org/10.1016/j.techfore. 2006.03.002.

[28] R.A.A. Suurs, M.P. Hekkert, Cumulative causation in the formation of a technological innovation system: The case of biofuels in the Netherlands, Technol. Forecast. Soc. Chang. 76 (2009) 1003-1020, https://doi.org/10.1016/j.techfore.2009.03. 002.

[29] S.O. Negro, M.P. Hekkert, R.E Smits, Explaining the failure of the Dutch innovation system for biomass digestion-A functional analysis, Energy Policy 35 (2007) 925-938, https://doi.org/10.1016/j.enpol.2006.01.027.

[30] L. Coenen, P. Benneworth, B. Truffer, Toward a spatial perspective on sustainability transitions, Res. Policy 41 (2012) 968-979, https://doi.org/10.1016/j.respol.2012. 02.014 .

[31] A. Bergek, M. Hekkert, S. Jacobsson, J. Markard, B. Sandén, B. Truffer, Technological innovation systems in contexts: Conceptualizing contextual structures and interaction dynamics, Environ. Innovation Soc. Transitions 16 (2015) 51-64, https://doi.org/10.1016/j.eist.2015.07.003.

[32] J. Markard, M. Hekkert, S. Jacobsson, The technological innovation systems framework: Response to six criticisms, Environ. Innovation Soc. Transitions 16 (2015) 76-86, https://doi.org/10.1016/j.eist.2015.07.006.

[33] J. Markard, R. Raven, B. Truffer, Sustainability transitions:a emerging field of research and its prospects, Res. Policy 41 (2012) 955-967, https://doi.org/10.1016/ respol.2012.02.013.

[34] K.M. Hillman, R.A.A. Suurs, M.P. Hekkert, B.A. Sandén, Cumulative causation in biofuels development: a critical comparison of the netherlands and sweden,
Technol. Anal. Strategic Manag. 20 (2008) 593-612, https://doi.org/10.1080/ 09537320802292826.

[35] D.J.C. Hawkey, District Heating in the UK: a Technological Innovation System Analysis, Environ. Innovation Soc. Transitions 5 (2012) 19-32, https://doi.org/10 1016/j.eist.2012.10.005.

[36] J. Markard, The life cycle of technological innovation systems, Technol. Forecast. Soc. Chang. 153 (2020) 119407, , https://doi.org/10.1016/j.techfore.2018.07.045.

[37] R.A.A. Suurs, M.P. Hekkert, Competition between first and second generation technologies: Lessons from the formation of a biofuels innovation system in the Netherlands, Energy 34 (2009) 669-679, https://doi.org/10.1016/j.energy.2008. 09.002 .

[38] J. Katz, Domestic technological innovations and dynamic comparative advantage: Further reflections on a comparative case-study program, J. Dev. Econ. 16 (1984) 13-37, https://doi.org/10.1016/0304-3878(84)90100-7.

[39] S. Lall, Technological learning in the Third World: some implications of technological exports, in: F. Stewart, J. James (Eds.), The Economics of New Technology in Developing Countries, Frances Pinter, London, 1982, pp. 157-179.

[40] L. Kim, Stages of development of industrial technology in a developing country: A model, Res. Policy 9 (1980) 254-277.

[41] X. Fu, C. Pietrobelli, L. Soete, The role of foreign technology and indigenous innovation in the emerging economies: technological change and catching-up, World Dev. 39 (2011) 1204-1212, https://doi.org/10.1016/j.worlddev.2010.05.009.

[42] A. Marin, V. Arza, The role of multinational corporation in national innovation systems in developing countries: from technology diffusion to international involvement, in: A.B. Lundvall, K.J. Joseph, C. Chaminade, J. Vang (Eds.), Handbook of Innovation Systems and Developing Countries, Building Domestic Capabilities in a Global Setting, Edward Elgar, Cheltenham, UK and Northampton, MA, USA, 2009.

[43] B. Oyeleran-Oyeyinka, R. Rasiah, Uneven Paths of Development, Innovation and Learning in Asia and Africa, Edward Elgar, Cheltenham, UK, Northampton, MA, USA, 2009.

[44] R. Arocena, J. Sutz, Looking at National Systems of Innovation from the South, Industry and Innovation 7 (2000) 55-75, https://doi.org/10.1080/713670247.

[45] C. Chaminade, B.A. Lundvall, J.K.J. Joseph, Designing innovation policies for development: towards a systemic experimentation-based approach, in: A.B. Lundvall, K.J. Joseph, C. Chaminade, J. Vang (Eds.), Handbook of Innovation Systems and Developing Countries, Building Domestic Capabilities in a Global Setting. Edward Elgar, Cheltenham, UK and Northampton, MA, USA, 2009, pp. 360-379.

[46] S. Lall, Technological Capabilities and Industrialization, World Dev. 20 (1992) 165-182, https://doi.org/10.1016/0305-750X(92)90097-F.

[47] C. Binz, B. Truffer, Global Innovation Systems-A conceptual framework for innovation dynamics in transnational contexts, Res. Policy 46 (2017) 1284-1298, https://doi.org/10.1016/j.respol.2017.05.012.

[48] I. Macedo, H. Nogueira, Avaliação da Expansão da Produção de Etanol no Brasil. Cadernos NAE, no 2, Biocombustíveis, Seção /2, Secom, Brasília (2004) 113-220.

[49] BETO (Bioenergy Technology Office), Multi-year Program Plan, U.S. Department of Energy, Office of Energy Efficiency and Renewable Energy, Washington D.C., March 2016. https://www.energy.gov/sites/prod/files/2016/07/f33/mypp_march2016. pdf.

[50] A.K. Chandel, V.K. Garlapati, A.K. Singh, F.A.F. Antunes, S.S. Silva, The path forward for lignocellulose biorefineries: Bottlenecks, solutions, and perspective on commercialization, Bioresour. Technol. 264 (2018) 370-381, https://doi.org/10 1016/j.biortech.2018.06.004.

[51] A.K. Chandel, J.Q. Albarelli, D.T. Santos, S.P.S. Chundawat, M. Puri, M.A.A. Meireles, Comparative analysis of key technologies for cellulosic ethanol production from Brazilian sugarcane bagasse at a commercial scale, Biofuels, Bioprod. Biorefin. 13 (2019) 994-1014, https://doi.org/10.1002/bbb.1990.

[52] A. Calil Neto, M.J.O.C. Guimarães, E. Freire, Business models for commercial scale second-generation bioethanol production, J. Cleaner Prod. 184 (2018) 168-178, https://doi.org/10.1016/j.jclepro.2018.02.220.

[53] A.A. Koukoulas, A Critical Look at Cellulosic Ethanol and Other Advanced Biofuels. Biofuels Digest, December 12 2016. https://www.biofuelsdigest.com/bdigest/ 2016/12/12/a-critical-look-at-cellulosic-ethanol-and-other-advanced-biofuels/.

[54] O.V. Carvalho-Netto, J.A. Bressiani, H.L. Soriano, C.S. Fiori, J.M. Santos, G.V.S. Barbosa, M.A. Xavier, M.G.A. Landell, G.A.G. Pereira, The potential of the energy cane as the main biomass crop for the cellulosic industry, Chem. Biol. Technol. Agric. 1 (2014) 20, https://doi.org/10.1186/s40538-014-0020-2.

[55] C. S. Ramos, Nova "cana energia" começa a ser usada em escala industrial, Valor Econômico, 16/11/ 2016. https://www.valor.com.br/agro/4776865/nova-canaenergia-comeca-ser-usada-em-escala-industrial.

[56] A.Y. Milanez, D. Nyko, M.S. Valente, L.C. Sousa, A. Bonomi, C.D.F. Jesus, M.D.B. Watanabe, M.F. Chagas, M.C.A.F. Rezende, O. Cavalett, T.L. Junqueira, V.L.R. Gouvêia, De promessa a realidade: como o etanol celulósico pode revolucionar a indústria da cana-de-açúcar - uma avaliação do potencial competitivo e sugestões de política pública, BNDES Setorial, 41, BNDES, Rio de Janeiro, 2015, pp. 237-294

[57] M. Scaramuzzo, BNDESPar paga R\$ 600 milhões por 15\% da GraalBio, Valor Econômico (21-01-2013.)

[58] C.S. Ramos, As idas e vindas de um projeto inovador, Valor Econômico (27/12/ 2018.)

[59] Raízen. 2019. Annual Report 2018/2019. https://www.raizen.com.br/relatorioanual/en/index.html.

[60] C.B. Corrêa, Parcerias Estratégicas Tecnológicas em Projetos de Etanol Celulósico: oportunidades e desafios para as firmas nacionais, Master Dissertation Institute of Geosciences, University of Campinas, Campinas, Brazil, 2014.

[61] J. Lane, Abengoa's Hugoton cellulosic ethanol project goes on the block, Biofuels Digest (18-07-2016.). 
[62] C.G. Silva, L.C.P. Mello, (Coord.). Ciência, Tecnologia e Inovação. Desafios para a sociedade brasileira. Livro Verde. MCT/Academia Brasileira de Ciências, Brasília, 2001.

[63] K. Pavitt, 1. The inevitable limits of EU R\&D funding, Res. Policy 27-6 (1998) 559-568.

[64] Brazil (2007).

[65] C.R. Frischtak, Vantagens Comparativas, Inovação e Economia Verde, Fórum Nacional (Edição Especial), Inter.B Consultoria Internacional de Negócios (Inter.B), Rio de Janeiro (2011).

[66] P.N. Figueiredo, H. Larsen, U.E. Hansen, The role of interactive learning in innovation capability building in multinational subsidiaries: A micro-level study of biotechnology in Brazil, Res. Policy 49 (2020) 103995, , https://doi.org/10.1016/j. respol.2020.103995.

[67] MAPA (Ministry of Agriculture, Livestock and Provision), Registro Nacional de Cultivares, 2018. http://www.agricultura.gov.br/guia-de-servicos/registro-nacional-de-cultivares-rnc, (Access 13 October 2018).

[68] M. G. A. Landell Cana Energia, Slides presented at the Fórum RAC 2017 - Caminhos da Retomada, Correio Popular, Campinas (2017) (Access in 9 January 2019).

[69] W. Suzigan, E.M Albuquerque, L.A.F. Cario (Orgs.), Em busca da inovação: Interação universidade-empresa no Brasil, Autêntica, Belo Horizonte, 2011.

[70] G.G. Gielfi, A.T. Furtado, A.S. Campos, R. Tijssen, A interação universidade-empresa na indústria de petróleo brasileira: o caso da Petrobras, Revista Brasileira De Inovação 16 (2017) 325-350 https://doi.org/10.20396/rbi.v16i2.8650114.

[71] M. Mazzucato, C. Penna The Brazilian Innovation System: A Mission-Oriented Policy Proposal, Temas Estratégicos para o Desenvolvimento, n¹. CGEE, Brasília, March 2016. https://www.cgee.org.br/temas-estrategicos.

[72] E. Balbachevsky, Processos decisórios em política científica, tecnológica e de inovação no Brasil: análise crítica, in: Nova geração de política em ciência, tecnologia e inovação: Seminário Internacional, CGEE, Brasília, 2010, pp. 61-90. https:// www.cgee.org.br/estudoscgee.

[73] A. Hira, L.G. Oliveira, No substitute for oil? How Brazil developed its ethanol industry, Energy Policy 37 (2009) 2450-2456, https://doi.org/10.1016/j.enpol. 2009.02.037.

[74] F.B. Dunham, J.V. Bomtempo, D.L. Fleck, A Estruturação do Sistema de Produção e Inovação Sucroalcooleiro como Base para o Proálcool, Revista Brasileira de Inovação 10 (2011) 35-72 https://doi.org/10.20396/rbi.v10i1.8649009.

[75] A.D. Andersen, A functions approach to innovation system building in the South: the pre-Proálcool evolution of the sugarcane and biofuel sector in Brazil, Innovation and development 5 (2015) 1-21, https://doi.org/10.1080/2157930X.2014. 996855.

[76] L. A. B. Cortez (Org.), Proálcool - Universidades e Empresas: 40 Anos de Ciência e Tecnologia para o Etanol Brasileiro, Blucher, São Paulo (2016), https://doi.org/10. $5151 / 9788521210627$.

[77] D. Nyko, J.L.F. Garcia, A.Y. Milanez, F.B. Dunham, A corrida tecnológica pelos biocombustíveis de segunda geração: uma perspectiva comparada, BNDES Setorial 32 (2010) 5-48 http://web.bndes.gov.br/bib/jspui/handle/1408/1312.

[78] D. Nyko, M.S. Valente, A.Y. Milanez, A.K.R. Tanaka, A.V.P. Rodrigues, A evolução das tecnologias agrícolas do setor sucroenergético: estagnação passageira ou crise estrutural? BNDES Setorial 37 (2013) 399-442 http://web.bndes.gov.br/bib/jspui/ handle/1408/1317.

[79] CGEE, (Center for Strategic Studies and Management), Second-generation sugarcane bioenergy \& biochemicals: Advanced low carbon fuels for transport and industry, Center for Strategic Studies and Management, Brasília, 2017.
[80] Ministério das Relações Exteriores, Brasília (September 2015).

[81] F. Batista, Raízen busca produzir etanol celulósico com custo do convencional, Valor Econômico (29-11-2013.).

[82] FINEP (Financiadora de Inovação e Pesquisa), PAISS (Plano BNDES-Finep de Apoio à Inovação dos Setores Sucroenergético e Sucroquímico), http://www.finep.gov.br/ apoio-e-financiamento-externa/programas-e-linhas/programas-inova/paiss, 2018 (Accessed on November 15, 2018).

[83] A.A. de Oliveira Filho, Mudanças e permanências no Sistema Setorial de Inovação da cana-de-açúcar: o caso do etanol celulósico, PhD Dissertation Institute of Geosciences, UNICAMP, Campinas, 2017.

[84] E. Almeida, P.V. Oliveira, L. Losekan, Impactos da contenção dos preços de combustíveis no Brasil e opções de mecanismos de precificação, Revista de Economia Política 35-3 (2015) 531-556 http://www.rep.org.br/PDF/140-9.PDF.

[85] EPE, (Energy Research Entreprise), Cenários de Oferta de Etanol e Demanda do Ciclo Otto 2018-2030, EPE, Ministério de Minas e Energia, Brasília, 2018.

[86] M.C.B. Grassi, G.A.G. Pereira, Energy-cane and RenovaBio: Brazilian vectors to boost the development of Biofuels, Ind. Crops Prod. 129 (2019) 201-205, https:// doi.org/10.1016/j.indcrop.2018.12.006.

[87] ABBI, (Brazilian Association of Industrial Biotechnology), A contribuição da biotecnologia industrial ao desenvolvimento brasileiro: O potencial do etanol de segunda geração e as alavancas para a sua viabilização, ABBI, São Paulo (December 2016).

[88] G, Silva Aprendizado do etanol celulósico no Brasil: o caso do projeto Dedini Hidrólise Rápida (DHR), Master Dissertation Institute of Geosciences, University of Campinas, Campinas, Brazil, 2013.

[89] A.O. Herrera, Los determinantes sociales de la política científica en América Latina: Politica Cientifica Explicita y Politica Cientifica Implicita, Desarrollo Económico 13 (1973) 113-134, https://doi.org/10.2307/3466245.

[90] J.A. Sabato, Ensayos de Campera, Juarez Editor, Buenos Aires (1979).

[91] L.L. Benites-Lazaro, N.A. Mello-Théry, M. Lahsen, Business storytelling about energy and climate change: The case of Brazil's ethanol industry, Energy Res. Social Sci. 31 (2017) 77-85, https://doi.org/10.1016/j.erss.2017.06.008.

[92] EPA (Environmental Protection Agency), Renewable Fuel Standard Program: Standards for 2019 and Biomass Based Diesel Volume for 2020. Federal Register Vol. 83, No. 237 (2018) / Tuesday, December 11/ Rules and Regulations.

[93] EIA (US, Energy Information Agency), EPA finalizes Renewable Fuel Standard for 2019, reflecting cellulosic biofuel shortfalls, EIA (2018).

[94] BETO (Bioenergy Technology Office), Strategic Plan for a Thriving and Sustainable Bioeconomy, U.S. Department of Energy, Office of Energy Efficiency and Renewable Energy, Washington D.C., December 2016. https://www.energy.gov/sites/prod/ files/2017/09/f36/beto_strategic_plan_december_2016.pdf.

[95] J. Lane, DowDuPont to exit cellulosic biofuels business, Biofuels Digest (02-112017.).

[96] J.V. Bomtempo, G. Soares Por que as primeiras plantas comerciais de etanol 2G são quase experimentais? Boletim Infopetro, Ano 16, 4 (2016) 33-37, Setembro/ Outubro. https://infopetro.wordpress.com/2016/10/19/por-que-as-primeirasplantas-comerciais-de-etanol-2g-sao-quase-experimentais/.

[97] Euroactiv, Can Advanced Biofuels Really Work? Special Report, 19 - 26 March 2018. http://eurac.tv/9Hxa.

[98] E.P.P. Souza, G.C. Pereira, L.X.L. Capanema, Avaliação do BNDES Funtec: uma análise sistêmica de efetividade, Revista do BNDES 45 (June 2016) 65-97 https:// web.bndes.gov.br/bib/jspui/handle/1408/9395. 